\title{
Partnership in Europe; its Variety, Trends and Dissolution
}

\section{A section of a work in progress}

DAVID COLEMAN, Oxford Centre for Population Research, Department of Social Policy and Intervention, University of Oxford

\begin{abstract}
Radical changes in living arrangements, in sexual habits and in the position of marriage in Europe have arisen, very unevenly, since the 1960s and in some regions in scarcely more than a decade. Cohabitation before marriage is normal - even universal - in many countries, with the popularity of marriage falling as its mean age rises to beyond the highest levels hitherto recorded. Divorce has been legalised and in most cases made readily accessible. However, although not as firm a demarcation as once believed, Hajnal's line separating East and West has not yet been erased from the map of contemporary Europe. The article describes patterns and trends in partnership in Europe, including trends in marriage rates, divorce rates, the spread of cohabitation, LAT-relations and of births outside marriage, and tries to account for them.
\end{abstract}

Key words: marriage, divorce, cohabitation, living apart together, births, Europe, second demographic transition

\section{Living together in Europe}

Almost all societies have an accepted institution, usually preceded by some rite de passage, whereby couples are publicly acknowledged to have reached adulthood and to be living henceforth in an exclusive sexual - and economic - relationship, wherein children will be produced. Thereby sex is controlled and reproduction is licensed, parentage and lineage acknowledged and demonstrated, the community affirmed and augmented. Modern Europe has now devised several such 'institutions', some private, some public, none universally acknowledged, some only grudgingly so, some routinely officially recorded, others ill-defined or detectable only though surveys and self-definition, some not capable of producing children although increasingly encouraged to foster them. Incest alone remains beyond the last frontier in Europe's regulation of its sexuality and living arrangements, and who knows how long that prohibition will last. Developments in sex and reproduction has gone very far in parts of Europe and its overseas descendants, creating a most varied society. The communitarian function of marriage, and the signal that partners could send by marrying, is correspondingly dimmed (Rowthorn 2002). Such traditional 'communities' as exist - mostly religious or immigrant - may 
have little in common with each other. Instead, individuals liberated from traditional constraints and partly buffered against the consequences of their choices by the entitlements of welfare can now follow a variety of independent life-courses.

These radical changes in living arrangements, in sexual habits and in the position of marriage in Europe have arisen, very unevenly, since the 1960s and in some regions in scarcely more than a decade. Divorce and abortion, the first difficult, the second almost universally illegal before the Second World War, have been legalised and in most cases made readily accessible in most Western European countries. Only in the Soviet Union in the pre-war period, and in the communist East after the 1940s, was divorce accessible and abortion (usually) lawful. In these respects the forced secularism of the Iron Curtain countries anticipated the more gradual changes in values developing in the West. However that was in a political and economic environment that seriously restricted other choices, in practice, if inadvertently, limiting the scope for union formation, or childbearing, outside marriage. In the West, on the other hand, the expansion of welfare and legal developments have facilitated divorce, removed the privileges of the married state and mostly abolished the formal distinction between legitimate and illegitimate birth. Sexual activity begins at younger ages and is now nearly universal before marriage. Cohabitation before marriage is normal - even universal - in many countries, with the popularity of marriage falling as its mean age rises to beyond the highest levels hitherto recorded.

As a consequence, what was once a fairly linear and one-way life-course has become much more branched, with opportunities to repeat experiences previously expected to be unique, and experience others hitherto almost unknown. A multiplicity of choices and sequences enables individuals to lead lives often much more different from each other than in the past. That in turn has promoted new techniques, notably event history analysis (Willekens 1999) for analysing these sequences and the factors influencing them.

Choices to marry, cohabit, live apart together, have children with a partner or without, reflect a new primacy of individual aspiration over traditional restraints and obligations to a wider society. New values and new behaviour together have been characterised as a Second Demographic Transition (Lesthaeghe and Meekers 1986). Their prevalence and progress in many countries is not in doubt, although some believe that the trends may not always be such a clear break with the past as has been claimed (Cliquet 1991). The notion has, however, become well established in demographic thinking (Sobotka 2008; Liefbroer and Fokkema 2008). The rate at which different populations have adopted these patterns have differed greatly, and this has created a renewed diversity within and between Western Europe's populations in sexual behaviour, living arrangements and family forms (Billari and Wilson 2001). In general, Southern Europe, whether Catholic or Orthodox, has been slower to fall for the attractions of the new regime, as has Germany but not Austria. On the other hand the Scandinavian countries, France, Britain and the rest of the English-Speaking world are statistically well in front. Most 
of the populations of Central and Eastern Europe, with more constrained choices, did not awaken to these possibilities until after the fall of communism, despite official indifference, indeed hostility, to the traditional religious mores that had helped constrain behaviour formerly. Socialist austerity and uniformity took its place, although that did not stop the Estonians emulating their Scandinavian neighbours at an early date, and for different reasons, a marked trend to births outside marriage in East Germany. This article will describe these patterns and trends and try to account for them.

\section{Historical background - three kinds of Europe}

In the past, the family: the 'rules' of marriage, the composition of households, set Europe apart from the rest of the world and in different ways still do. In a number of ways Western Europe, more specifically North-Western European patterns could be distinguished from those of Eastern Europe. Aspects of a distinctive 'Western European marriage pattern' became visible in the $16^{\text {th }}$ century and lasted relatively unchanged until the 1930s, in some regions even up to the 1960s. Late marriage, frequent lifelong spinsterhood, households based on the nuclear, not the extended family, low levels of cohabitation and illegitimacy were normal (Flinn 1981; Mitterauer and Sieder 1982; Therborn 2004). A young couple were expected to live in a new household of their own on marriage, and not to marry until they could do so: the so-called 'neolocal household formation rules'. Based on the new techniques for exploiting historical parish records developed by Fleury and Henry, John Hajnal $(1965,1982)$ was the first to demonstrate these distinctions statistically. East of 'Hajnal's line', from Trieste to St Petersburg, families in Eastern Europe and the rest of the world were different; very diverse but most sharing a pattern of nearly universal and early marriage for women, residing in households frequently complex, a view supported by 19 th and early $20^{\text {th }}$ century census and vital statistics evidence (Coale and Watkins 1986). A unique feature, most developed in Britain, was the pervasive presence of young people from other families, helping with the domestic economy as 'husbandry servants' (Kussmaul 1979).

Recent scholarship has made holes in this nice picture, turning the 'West European' pattern into something of a patchwork; strong in most of North-West Europe, absent in much of Spain and in Italy where marriage was regionally more universal, families more extended and households more complex (Benigno 1989); contrasts which have retained their sense of place (Reher 1998; Haavio-Mannila and Rotkirch 2010). Western household arrangements appear less distinctive when economic circumstances are taken into account (Ruggles 2009). Furthermore, a few, mostly rural areas preserved historically high levels of cohabitation and illegitimacy: Iceland, parts of rural Austria and Sweden (Laslett, Oosterven and Smith 1980). And the statistical differences across Hajnal's line were hardly precipitous, as critics have noted, within Europe and many features of the 'Western' pattern can be found outside Europe (Goody 1996; Lee and Feng 1999). Much more is now known about Eastern Europe and its marital diversity (Szoltysek 2007, 2008), 
further reducing the East / West contrast. But although not as firm a demarcation as once believed, Hajnal's line has not yet been erased from the historical map of Europe, nor even from the contemporary one.

Because in the past births outside marriage were rare, and deliberate contraception and abortion little practiced if at all, marriage governed the birth rate. Therefore if marriage was late and variable, so was the output of births. Marriage in turn responded to trends in real wages, partly through adjustment of the duration of husbandry service. If fertility responded to the economy, in Malthus' scheme of things the economy also responded to fertility, the increased supply of labour arising from an upturn in births eventually depressing real wages and turning down the marriage valve - creating a grand sequence of cyclical feedbacks (Wrigley, 1986). This has only been demonstrated thoroughly for pre-industrial agrarian England (Wrigley 1981; Wrigley et al. 1997); mercantile Holland beat to a different rhythm (De Vries 1986) while Ireland fell into the grip of a much harsher Malthusian model (Houston, 1992; O Grada 1993). Even more ambitious claims have been made for the importance of this system of variable marriage with its feedbacks on fertility and economy; its crucial role in facilitating a 'low-pressure' demographic regime of moderate birth and death rates, its seminal relationship to savings, mobility, markets and the rise of capitalism and the need it created for external systems of welfare to compensate for the highly variable age- and dependency patterns of the nuclear household over its life-course (Macfarlane 1986).

Although the timing of life-events is still sensitive to economic change, and in the longer run, demographic change still in turn has powerful economic effects (for example through the 'baby boom'), this demographic regime no longer operates. With radical changes in economy and in attitudes, prosperity opens up new freedoms of choice, welfare cushions economic hardship and helps insulate individuals from the consequences of their reproduction, prudent or otherwise. Marriage has lost its attractions for many in Europe as women no longer depend on a man's income, traditional values and restraints are superseded.

By the 1930s, in most developed countries, deferred gratification to contain family size by delaying marriage had been made logically redundant by contraception. After what was perhaps an inevitable delay, age at marriage in many European countries started to decline in the 1930s; clearly visible in the data of Sweden and Switzerland (Sardon and Calot 1997), uninterrupted by war. The alacrity with which different European populations seized their new opportunities varied greatly (Szreter 1996) according, it would seem, to their attitudes towards sex. Perhaps predictably, the British were among the last to see the new possibilities. Western Europe's love affair with marriage, interrupted in most countries by the war, resumed in the 1950s with renewed force, propelled by the most substantial economic boom ever recorded (Crafts and Mills 1995). By around 1972 that took mean ages at marriage to low levels never seen 
in Western Europe for centuries and never since. Mean age at first birth followed the trend in marriage, and together with larger completed family size promoted the 'baby boom'. This was arguably the last fling of the simple Malthusian connection between wages and fertility uncomplicated by women's workforce contributions.

If anything, communist rule after 1920 in the old Russian Empire and in Central and Eastern Europe after 1945-8 accentuated East-West differences in marriage pattern and therefore the timing of childbearing. It also 'Easternised' the demographic behaviour of some counties historically west of Hajnal's line that after 1945 found themselves on the wrong side of the Iron Curtain (the Baltic States, the Czech lands, East Germany). Their marriage patterns changed after the Red Army pushed Hajnal's line several hundred miles further west and different rules and incentives began to apply. Under Communism, married life became one of the last refuges of the private realm as well as being in some countries a passport to housing allocation. Most Eastern European populations have never shared the 'West European Marriage pattern' of late marriage, common lifetime celibacy and households based on nuclear, not extended families $(\mathrm{Ni}$ Bhrolchain 1993; Rychtarikova 1993) but after the fall of Communism some of these features have arrived fast (not, perhaps, the celibacy).

Since then, the story in the West has been one of pervasive postponement of formal unions and of childbearing amidst a broadening of choices, and hence dilemmas and compromises, unknown to previous generations. In most $20^{\text {th }}$ century European societies up to the 1950s, the transition to a sexual union, almost always marriage, most often went hand in hand with leaving home. Husbandry service was by then extinct. Only a minority of young unmarried people lived away from home; students away at university especially in Britain, those in the armed services, those obliged to leave home, often to live in temporary accommodation, to seek work, those who had quarrelled with parents or step-parents. Generally, most young people lived at home until marriage, except those forced by circumstances to stay after marriage with parents as 'concealed households', especially after the war, or included patrilocally by custom, in parts of the South.

Now the position is much more diverse. Higher education takes many away from home and home-town to live communally or in small student households, higher wages and a more mobile workforce create a new habit of flat and house sharing by unrelated young people, mostly in better-paid occupations, welfare may enable unmarried or cohabiting people with children to live independently in social housing. Geographically the pattern is most varied. Up to the end of the 1980s, cohabitation was most prevalent in Northern Europe, being almost unknown in the South (Haskey 1992). There, even in the 2000s, the delay in marriage is not spent much in residential independence. Instead residence in the parental home is delayed up to the late $20 \mathrm{~s}$ or even $30 \mathrm{~s}$ in what Billari et al. (2002) have called 'latest-late' home leaving behaviour by those whom the Japanese call 'parasite singles'. In Italy, later marriage has meant little growth in 
any transitional period of independent flat-dwelling or cohabitation. Indeed among the most recent cohorts of young Spanish and Italian men (born 1965-74) fewer were living apart and fewer cohabiting than in earlier post-war cohorts. Young people in other more traditional - invariably Catholic - countries outside Southern Europe, such as Belgium and Poland tend also to stay at home - later and later - until marriage.

\section{The broad picture of marriage - a look at cohorts}

The proportions of successive cohorts of women and men, born since the 1930s who ever marry have fallen substantially since the 'golden age' of marriage in the immediate post-war period, and continue to fall almost everywhere. In all periods of time it has been rare to marry for the first time after age 50 and chances are thin even after age 40 , especially for women. The proportion of any cohort ever-married (that is, currently married, divorced or widowed) by age 50 age is taken as a conventional limit beyond which little further change occurs.

The generations born around 1945 were the most married in Western European history. In most countries well over $90 \%$ of women born in the 1930s and 1940s, and therefore marrying around the 1950s and 1960s married at least once; the highest proportion for centuries. That helped to fuel the baby boom of those years. Even then, however, some diminution in the proportions married was apparent in those countries leading the retreat from marriage - Switzerland and Austria, followed by Sweden.

These, together with other Nordic countries, have continued a trend away from marriage. Even so in most Western European countries in 2010 except Sweden, Finland, France and Norway, over 80\% of women aged 45-49 (born in the 1960s) had married at least once, and over $70 \%$ of men (except in Sweden) had done so. But in more recent cohorts, fewer have married. Among people aged 30-34 (born around 1980) only about $50 \%$ of women (even fewer in Sweden) had married by that age, and $40 \%$ of men; fewer than $40 \%$ in Sweden, Norway, Germany, The Netherlands and Italy (Table 4.1).

With a few exceptions marriage remains the norm - just - in the sense that so far in most countries most couples aged 50 have married and among couples the currently married exceed the numbers cohabiting, although in North-West Europe usually not before the birth of at least one child. Marriage remains more secure in Southern and Eastern Europe, although delayed, even though extra-marital fertility is increasing from modest levels. In North Western Europe, however, the prevalence of marriage has fallen to low levels never even seen in previous centuries, when marriage was delayed and often avoided, although unlike today usually in a celibate state.

The 'total first marriage rate' (TFMR) is the analogue for marriage of the 'total fertility rate' but calculated separately for men and for women. It shows the proportions who will ever marry that are implied by the continuation of current first marriage rates 
(Hinde 1998). Like the total fertility rate, it is sensitive to changes in tempo; so when age at marriage was falling in the West in the 1950s and in the republics of the former Soviet Union until the early 1990s, apparently absurd total first marriage rates of over one first marriage per person were commonplace. More recently the delay in marriage has caused the total first marriage rate to fall to very low levels that are unlikely to be experienced by any real cohort. As age at marriage is changing at a similar pace in many countries, however, the TFMR remains a reasonable basis for comparison even if the absolute value may be hard to interpret.

Table 1. Percentage of ever married men and women (in 2010 if not mentioned).

\begin{tabular}{lcccc|cccc}
\hline & \multicolumn{4}{c|}{ Women } & \multicolumn{5}{c}{ Men } \\
& $\mathbf{3 0 - 3 4}$ & $\mathbf{3 5 - 3 9}$ & $\mathbf{4 0 - 4 4}$ & $\mathbf{4 5 - 4 9}$ & $\mathbf{3 0 - 3 4}$ & $\mathbf{3 5 - 3 9}$ & $\mathbf{4 0 - 4 4}$ & $\mathbf{4 5 - 4 9}$ \\
\hline Sweden & 46,2 & 59,6 & 66,6 & $\mathbf{7 1 , 4}$ & 33,6 & 49,2 & 58,3 & 64,1 \\
Switzerland & 60,6 & 75,8 & 82,7 & 86,5 & 45,3 & 63,9 & 75,3 & 82,3 \\
Finland & $\mathbf{5 6 , 9}$ & 68,0 & $\mathbf{7 2 , 9}$ & $\mathbf{7 7 , 5}$ & 44,4 & 58,8 & 65,1 & 70,1 \\
Austria & 55,4 & 71,2 & 79,5 & 86,3 & 41,2 & 59,4 & 71,5 & 79,7 \\
Denmark & 55,7 & 71,1 & $\mathbf{7 8 , 2}$ & $\mathbf{8 1 , 5}$ & 41,2 & 60,6 & 70,2 & 74,5 \\
France & 51,3 & 63,5 & 72,1 & $\mathbf{7 9 , 3}$ & 41,1 & 56,3 & 66,2 & 73,9 \\
Iceland & 70,9 & 79,8 & 83,7 & 86,0 & 61,7 & 74,7 & 79,8 & 83,2 \\
Norway & 50,6 & 63,5 & 72,2 & 78,9 & 36,9 & 53,5 & 64,2 & 72,0 \\
Germany & 53,2 & 67,2 & 75,9 & 83,9 & 37,8 & 54,9 & 65,3 & 75,1 \\
Spain (year 2001) & 68,9 & 82,0 & 87,3 & 89,8 & 54,3 & 73,8 & 82,8 & 87,0 \\
Ireland & 51,1 & 68,5 & 77,8 & 83,5 & 42,5 & 63,3 & 74,0 & 79,6 \\
Belgium (year 2009) & 57,0 & 72,3 & 82,4 & 87,9 & 44,5 & 61,8 & 74,3 & 81,8 \\
Netherlands & 52,1 & 67,3 & 77,2 & 83,7 & 37,9 & 55,9 & 68,3 & 77,2 \\
UK & 52,2 & 68,2 & 78,0 & 84,9 & 42,7 & 61,3 & 72,4 & 79,9 \\
Italy & 57,9 & 72,7 & 81,2 & 85,9 & 38,8 & 59,1 & 72,9 & 81,3 \\
Portugal (2001) & 83,8 & 89,5 & 92,1 & 93,3 & 75,3 & 85,3 & 90,2 & 93,3 \\
\hline
\end{tabular}

Source UN.

The trend in total first marriage rate for a set of geographically defined groups of countries is given in Figure 4.1. In these groups the unweighted mean is used. That is because we are interested here in the behaviour of the average European political and cultural entity, not some notional 'average European'. The extreme upswing in the late 1980s in the Scandinavian group is genuine; Swedes flocked to marry in 1988 following a welfare reform that rewarded the marital state. So much, as some have noted, for Scandinavian post-materialism. 


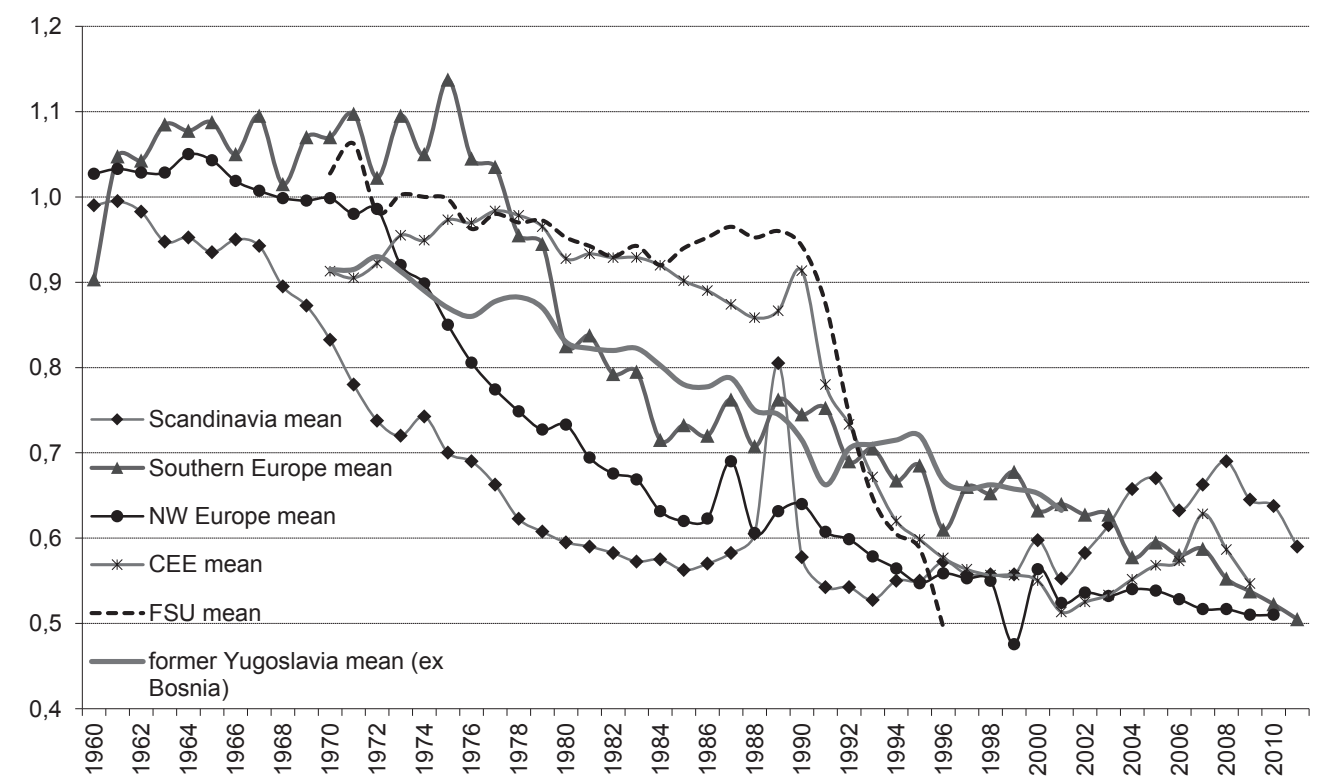

Figure 1. Total First Marriage Rate, groups of European countries. Source of data: Council of Europe, Eurostat, National Statistical Yearbooks.

The trends for a selection of individual countries are given in Figure 2.

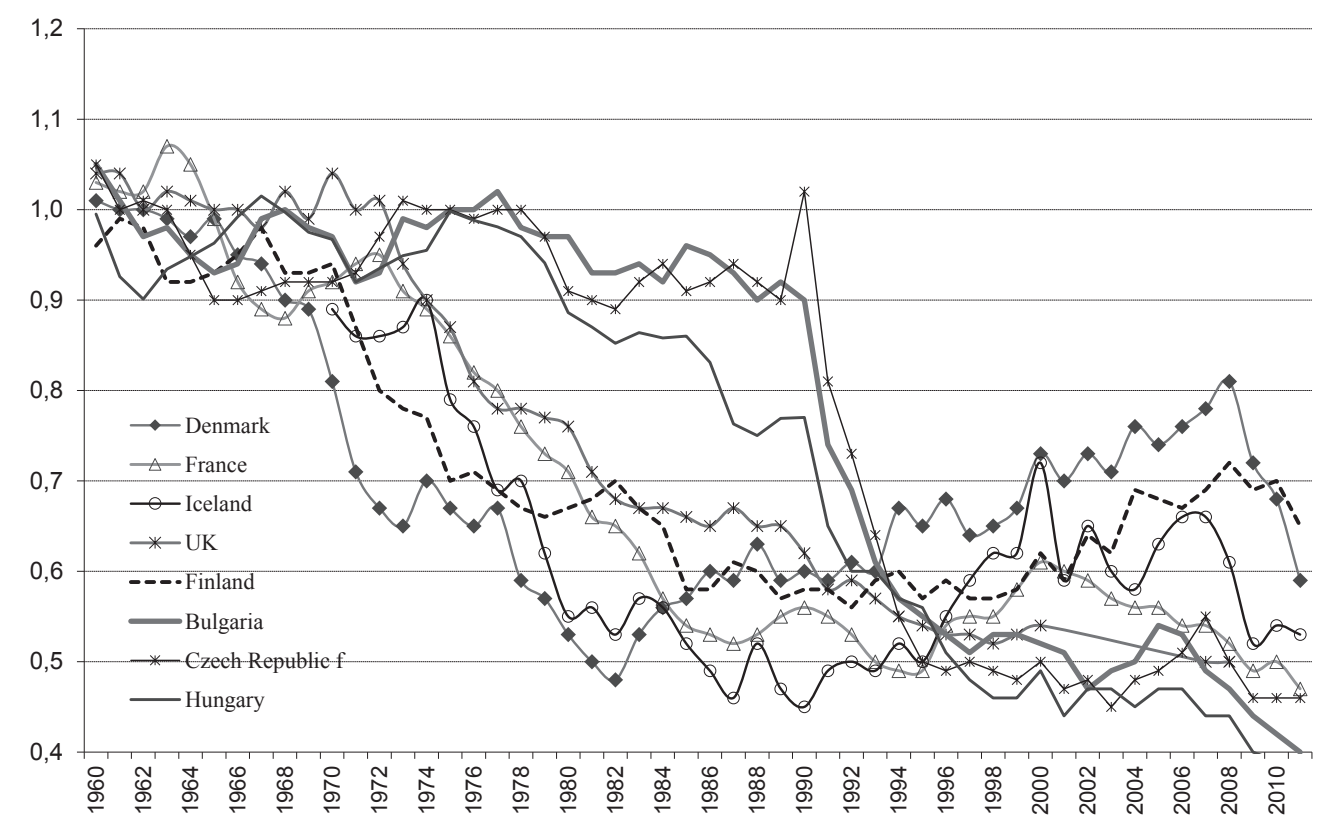

Figure 2. TFMR of selected European countries. Source of data: Eurostat. 
It is unfortunate that comparable published data in these and so many other demographic series begin around 1960. In Western Europe that year was close to the height of the baby boom with its unprecedented marriage rates and proportions married - much higher than previous decades. In Southern Europe and North-West Europe the series average over 1.0 until the 1970s, reflecting the increasing youthfulness of marriage until the early 1970s and probably, in the case of the Southern European countries, the habit of guest-workers returning to the home country for weddings when registered as residing abroad. By the mid-1990s however, TFMR fell to 0.5 or 0.6 in North and Western Europe and to between 0.6 and 0.7 in Southern Europe (Figure 4.1). A considerable diversity has opened up amidst this uneven decline; in 2005 TFMR in Estonia was 0.45 , in Italy 0.58 , in Denmark 0.74 .

After the 1970s, high marriage rates were only found in the communist East; the former Soviet Union and the countries of the Warsaw Pact. There, the high marriage rates typical of most of Eastern Europe were if anything accentuated by the conditions under communism until the collapse evident from 1989/1990. That collapse from previously very high marriage rates has been spectacular, although it is not yet matched by a commensurate increase in average age at marriage. In 2002 in all the CEE countries and the former Soviet Union except Lithuania, Moldova, Poland and Romania, TFMR had fallen below 0.5. For a short while, TFMR in the former East Germany fell from 0.6 in 1990 to 0.31 in 1991. We lack recent data for the Russian Federation; suitable data on marriage are no longer collected. But in 1996 TFMR had already fallen to 0.6 from 1.0 in 1990. In Soviet times, everyone married. What else was there to do?

At the other end of the scale, marriage rates in Scandinavia began falling away in the 1960s, followed five years later by the North-West European countries and over a decade later by Southern Europe. Taken at face value, the average TFMR for the Scandinavian, NW and Central European countries - about 0.6 - implied that not more than $60 \%$ of women there would eventually marry. By the first few years of the $21^{\text {st }}$ century, rates appeared to have stabilised, with marriage rates in some Southern European countries (Italy 0.5 , Spain 0.55 ) having fallen notably lower than in some of their Northern neighbours by around 2005. The individual countries in Figure 4.4 illustrate these points in detail, the case of Bulgaria underlining the very different experiences of Eastern Europe until 1990 when TFMR had plunged to 0.47 in 2002, a nadir previously only matched by Iceland.

However marriage rates can go up as well as down. Around 2000 Denmark and Iceland had their highest marriage rates for 30 years and in France, Finland and elsewhere marriage rates also increased. That might indicate a slowing down in the postponement of marriage, analogous to the recuperation of fertility seen over the same period (Bongaarts and Feeney 1998). Adjustment of TFMR to take tempo changes into account has shown that in some countries, for example in Austria, Germany and Switzerland, 
much of the depression of total first marriage rate up to 2000 can be shown to be due to the effect of postponement (Winkler-Dvorak and Engelhardt 2002). Despite that, the trend in mean age at marriage illustrated below showed no sign of halting up to 2010, with the possible exception of Denmark. The effect of the economic crisis from 2008 in depressing marriage rates is apparent in all the countries illustrated in Figure 4.4 and in most others for which we have data.

\section{Mean age at marriage}

Mean age at marriage generally continues to rise, proportions married at given ages continue to fall, while most surveys indicate some continued attachment to the idea of marriage - eventually. By the early years of the 2010s, women in North and West Europe were marrying at the latest ages ever recorded in their respective countries: Swedish women in 2011 taking the first place (33.0 years in 2011). Mean age at first marriage in 2011 was over 30 years in most of Western Europe The similarity of the more moderate trends in Germany, France and the UK, depicted in Figure 4.3, is striking, now joined by formerly divergent Spain and Finland. Formerly, women in Southern European countries women married somewhat younger. But by 2011 the average age at first marriage of women in Portugal had risen to 28.8 and in Greece to 29.2, while women in Italy and Spain now marry as late as their sisters in Northern countries, with mean age at first marriage of 30.6 and 31.3 respectively in 2011. Late marriage moved like a wave from the North-West of Europe to the East. In Scandinavia, mean age at marriage started to rise again around 1967, in NW Europe around 1973, as also in the republics of former Yugoslavia, although more slowly and at a lower level. Southern Europe followed around 1980, while the CEE countries and the republics of the former Soviet Union did not follow the trend until 1990 and 1992 respectively (Figure 4.3a), but at a similar pace to all the other regions. In the East, static communist societies and static planned economies, free of the roller-coaster excitements of Western economic booms and busts that powered free market marriage and fertility rates, provided thirty years or more of marital peace and quiet unmatched elsewhere (Figure 4.3b). All that changed after 1989, with the abrupt institution of an upward trend in age at marriage in the CEE countries after 1990 - for example the Czech Republic and Bulgaria - is particularly notable.

By no means all former communist countries reacted to the shock of the demise of the old regime by delaying marriage, however. In a few cases, at least in the earlier 1990s, mean age at first marriage actually fell very slightly for a time, although those first marriages were reduced in number compared with previous years and represent a rather selected group of the population. Mean age at first marriage remained relatively youthful in some Eastern European countries by 2011, for example Romania (25.9) and Poland (26.2). In Ukraine and Belarus the earlier upward trend has not been maintained. There, mean age at first marriage in 2011 remained at a very un-European 24. 


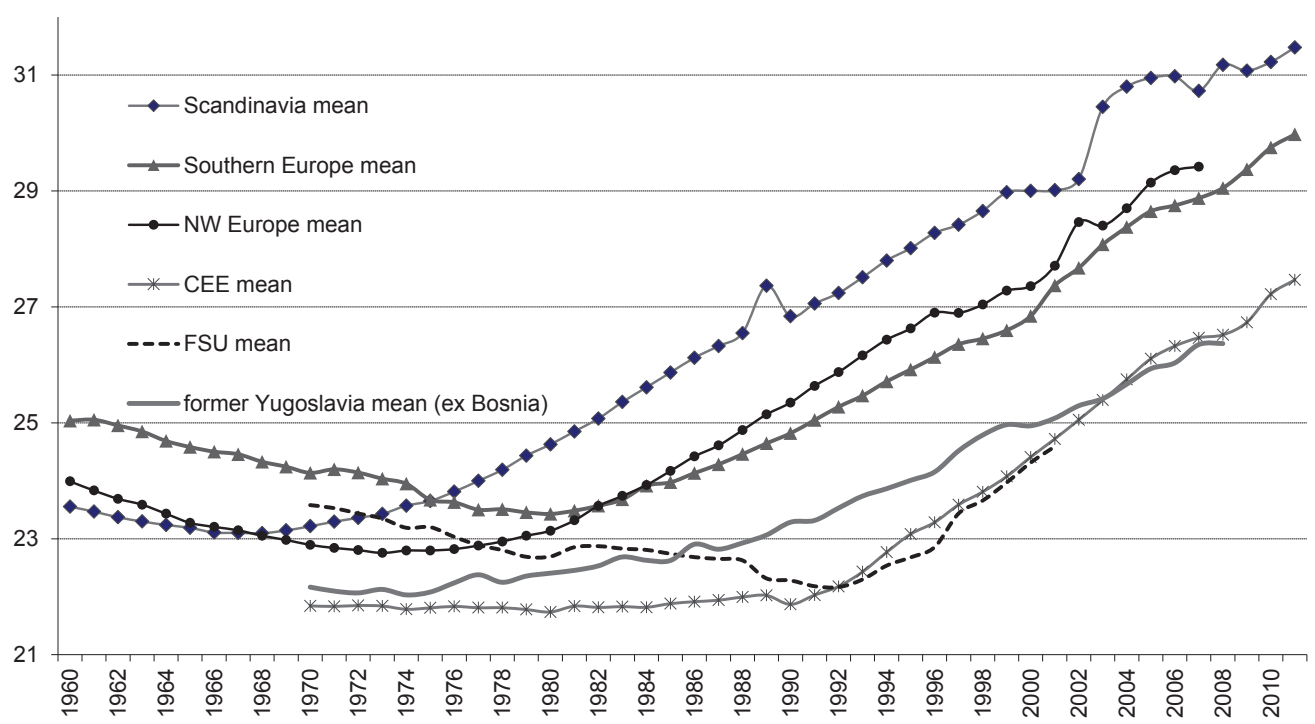

Figure 3a Mean Age at First Marriage - European regions 1960-2011.

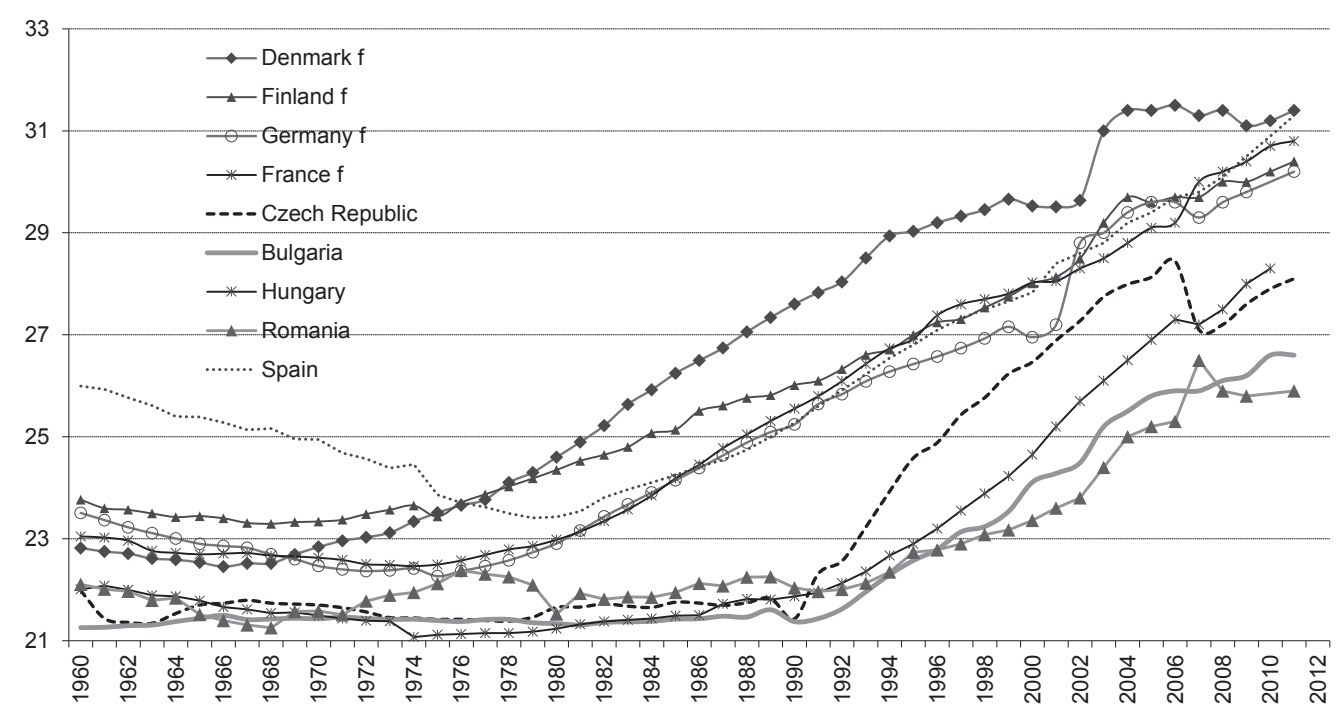

Figure 3b. Mean Age at First Marriage - selected European countries 1960-2011.

Mean age at marriage, is of course only a simple summary measure. But in most countries it is quite a sensitive one because (first) marriage had always been concentrated in a small part of life, from the mid-20s to early 30 s. In Western countries, very few marry as teenagers except for immigrant minorities. 


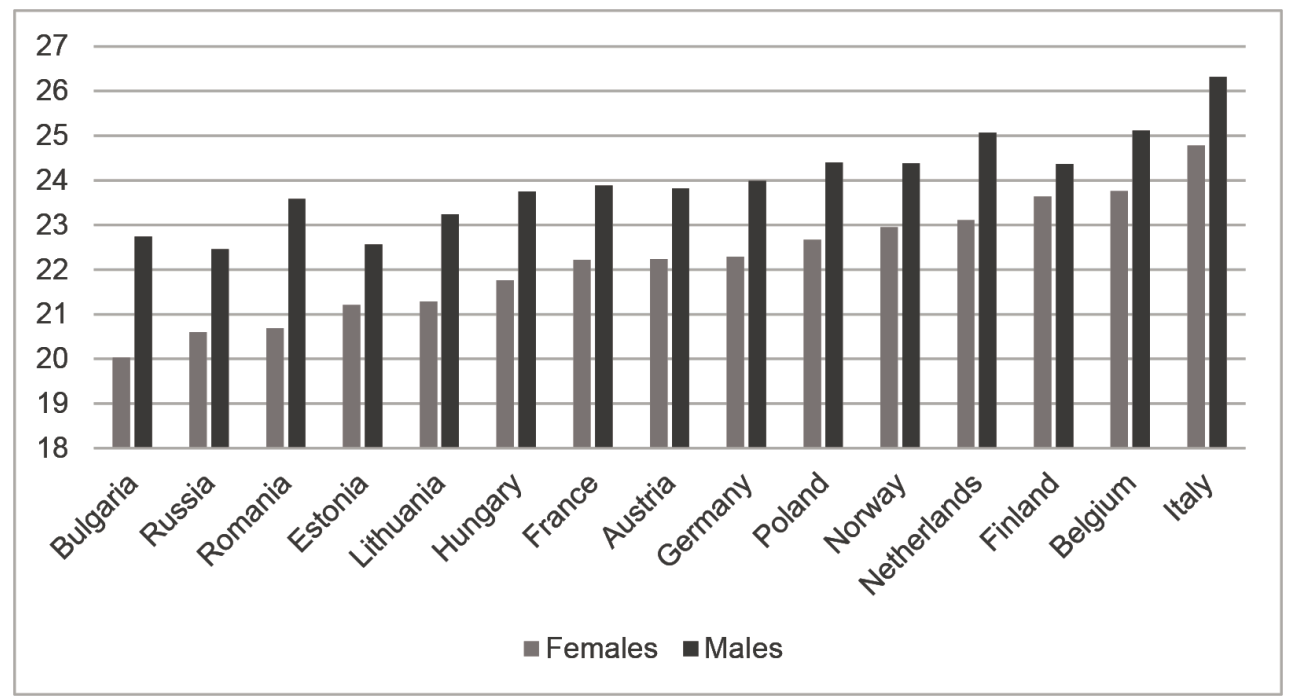

Figure 4. Mean age at first partnership, married or cohabiting, selected European countries around 2005.

Until the 1960s, international differences in mean age at marriage represented real differences in the age when couples began living together. Nowadays, however, young people are in fact getting together much earlier that the marriage statistics indicate although not necessarily retaining the same partner (Figure 4.4). Southern European countries still have lower levels of cohabitation that those of North-West Europe. So while age at marriage is higher in North-West Europe, mean age when women form their first union is younger than in some Southern countries, notably Italy. The youngest ages for partnership formation in the countries taking part in the Gender and Generations Surveys are in Eastern Europe, for example in Bulgaria where about half of teenage girls were already in a partnership in 2005. Thus union formation remains youthful in many countries, or has become even more youthful, despite the retreat from marriage. These first, informal unions however tend to be rather fragile.

The populations with later union formation, of any kind, are in a group of countries in Western and Southern Europe: Germany, Switzerland, Spain and Serbia, where marriage is delayed and cohabitation still not the norm. When Europeans are asked about their intentions, a different picture emerges. Various surveys in the 1990s suggested that in many European countries at least $85 \%$ of women may eventually marry, albeit in many cases after a period of cohabitation (e.g. Palomba and Moors 1995).

\section{The implications of current trends}

What does all this mean for the future of marriage and partnership? In many countries, the TFMR was between 0.85 and over 1.0 even up to the end of the 1980 s, reflecting the youthful tempo of marriage in the earlier post-war period. Now, in much of 
Europe, TFMR has fallen to between 0.5 and 0.6 . Taken at face value, that suggests that nearly half of the populations concerned will avoid marriage altogether. That is implausible, given the known distorting effects of postponement and the results of surveys of intentions. Life-table methods provide better estimates of proportions of the unmarried ever-marrying by given ages ('nuptiality'), usually up to age 50 (Hinde 1998; Haskey 1996). These life-table calculations need more data than the TFMR measure (population by marital status and age as well as marriages by age). So for most countries they are not generally available. This nuptiality calculation yields more reasonable results because it relates the events (marriages) to the populations at risk (the never-married) in each age-group. 'Gross nuptiality' does not allow for the attrition of marriage by mortality, 'net nuptiality' does so. Thus for example in France in 1963, the total first marriage rate was 1.07 compared with the life table calculation of 0.95 ; in 1994 the total first marriage rate had fallen to 0.49 while the 'nuptiality' figure for the same years remained at 0.65 (Toulemon 1996, table A1). In Britain, the total first marriage rate for 2000 was 0.54 (Council of Europe 2003 t2.2) while the 'gross nuptiality' figure was 0.68 (ONS Series FM2 no. 28 t 3.21). Projections of marriage rates and proportions marrying in England and Wales (based on 1996 data) expected mean age to rise to 32.6 for bachelors and 30.3 for spinsters by 2011, with only $66 \%$ of men, and $71 \%$ of women, ever marrying (Shaw 1999). The projection of mean age for 2011 was almost exactly correct, the actual average ages being 32.2 and 30.2 years respectively.

But the 'people' to whom the calculations relate are still imaginary people, combining instantly the experiences of different cohorts of real individuals into one synthetic one. Hence earlier marriage will still inflate the estimate, and later marriage age will still deflate it. We will have to wait until real cohorts live more of their lives to see if marriage really is on the run, or not, to the extent that these measures suggest.

All these data emphasis not just the changes that are taking place across most European countries but also the variety that persists, and in the early $21^{\text {st }}$ century is often increasing between them. It is not just that national populations differ greatly in the proportions of their citizens currently married, cohabiting or living apart together, or even that households in the same street now show the same variety. The nature of partnership itself has changed very unevenly.

\section{Cohabitation}

Marriage is impossible to measure or to understand without considering cohabitation. Union formation is now considerably earlier in most North and Western European countries than marriage data suggest, because cohabitation has become a preliminary to marriage for most of the couples there. In North-West Europe and North America, cohabitation has displaced marriage in the early lives of most couples, often as an 
accepted preliminary to marriage, increasingly as a normal form of union without marriage, and as a setting for the birth at least of the first child. Until the early 2000 s, the Southern European countries have been more resistant, although it has gained ground in Eastern Europe. 'Nuptial' cohabitation has become the norm, both statistically and in the moral sense, in some northern countries, notably Sweden. There, not only is marriage without cohabitation frowned upon, but it is normal to defer marriage at least until the first child is born. In many cases marriage is avoided altogether for ideological or other reasons.

In the nature of things, statistics on cohabitation are more troublesome than those of legally registered events, except in those few countries sufficiently well organized to record them routinely (e.g. Denmark), and that on a voluntary basis. Most information comes from surveys. Informal unions and their dissolution can provoke almost as many complications over property and children as marriage, and as their prevalence grows and their participants demand legal equality with marriage there is growing pressure to register them. Entitlements, so far, however have run ahead of registration so that neither legal proceedings nor data are very satisfactory. Some censuses now ask appropriate questions (Sweden, Great Britain). More data come in various forms, not always compatible: longitudinal life-course data from the Fertility and Family Surveys and Gender and Generation Surveys of the UN ECE, panel data from the EU Household Panel Survey and the British Household Panel Survey, cross-sectional enquiries relating to a single calendar year such as the Eurobarometer and Labour Force Surveys for EU countries, and national enquiries such as the General Household Survey (GB). No single source provides comparable data on all countries. The World Values Survey comes close but is held only infrequently.

All sources show (e.g. Table 2) differences in the experiences of young people living in different countries and regions, varying on a fairly predictable geographical basis. But cohabitation is almost everywhere more prevalent than in the 1990s. The European Social Survey of 2012 indicates that over 20\% of men aged 25-29 were currently cohabiting and between 30 and $50 \%$ in the Nordic countries, Belgium and the Netherlands. Other data place France at a similar position. However these proportions are very high compared with other sources, and the data for men and for women do not fit well. Accordingly older but possibly more reliable data are presented here from Eurostat and from the OECD.

In these data, between 20 and $30 \%$ of persons in the Northern European countries around the year 2000 were living with an unmarried partner, and rather high proportions - in many cases over one fifth - were living alone. Only in two countries in the whole of Europe were fewer than $25 \%$ living with their parents. Outside Northern Europe, fewer than $15 \%$ were cohabiting, and in most countries fewer than one in ten. Proportions living alone diminished correspondingly, with generally higher proportions married or living with parents. 
Table 2. Proportions of both sexes according to living arrangements, around 2000 , persons aged $20-34$, arranged by descending order of proportions cohabiting. Source: OECD http://www.oecd.org/social/soc/oecdfamilydatabase.htm

\begin{tabular}{|c|c|c|c|c|c|}
\hline & \multicolumn{5}{|c|}{ ages $20-32$} \\
\hline & $\begin{array}{c}\text { Single, } \\
\text { living alone }\end{array}$ & Married & Cohabiting & $\begin{array}{l}\text { In parental } \\
\text { home }\end{array}$ & Other \\
\hline Denmark & 34 & 25 & 29 & 8 & 5 \\
\hline Finland & 21 & 27 & 28 & 18 & 6 \\
\hline Estonia & 14 & 32 & 24 & 27 & 3 \\
\hline Norway & 21 & 25 & 23 & 27 & 5 \\
\hline United Kingdom & 11 & 32 & 22 & 25 & 10 \\
\hline Netherlands & 20 & 30 & 22 & 20 & 9 \\
\hline France & 19 & 21 & 22 & 38 & \\
\hline Austria & 15 & 33 & 14 & 32 & 6 \\
\hline Germany & 20 & 34 & 14 & 24 & 9 \\
\hline Ireland & 6 & 28 & 13 & 45 & 8 \\
\hline Switzerland & 21 & 35 & 12 & 21 & 11 \\
\hline Hungary & 7 & 39 & 12 & 36 & 7 \\
\hline Luxembourg & 18 & 23 & 11 & 47 & \\
\hline Slovenia & 4 & 28 & 9 & 57 & 3 \\
\hline Lithuania & 15 & 69 & 8 & 0 & 7 \\
\hline Romania & 3 & 49 & 7 & 31 & 9 \\
\hline Latvia & 8 & 35 & 6 & 51 & 0 \\
\hline Portugal & 4 & 41 & 6 & 39 & 11 \\
\hline Spain & 5 & 27 & 6 & 52 & 10 \\
\hline Belgium & 19 & 22 & 5 & 54 & \\
\hline Czech Republic & 12 & 39 & 4 & 40 & 5 \\
\hline Greece & 6 & 36 & 3 & 46 & 9 \\
\hline Italy & 6 & 31 & 3 & 51 & 10 \\
\hline Bulgaria & 6 & 19 & 3 & 72 & \\
\hline Cyprus $^{4,5}$ & 4 & 48 & 2 & 34 & 12 \\
\hline Poland & 8 & 41 & 2 & 44 & 6 \\
\hline Slovak Republic & 11 & 41 & 2 & 43 & 4 \\
\hline Malta & 3 & 31 & 1 & 65 & \\
\hline
\end{tabular}

In the 1990s, most young people in Eastern European countries were already married, as was traditional; neither cohabiting nor living alone. While the data above show that proportions married had fallen somewhat by 2000 , the unmarried were mostly living with parents, not cohabiting or living alone. In Southern Europe, especially in Italy and Spain, many young people did not live in partnerships of any kind, being much more likely to continue living with their parents until marriage (Kiernan 2002a). This preference for living at home and being cared for by parents into the late $20 \mathrm{~s}$ or beyond had been growing in Italy and Spain in the 1990s (Palomba 2001). About half of young women in Italy, Spain and in West Germany are likely to have experienced no 
(co-residential) partnership of any kind by age 25, unlike most other Western European countries where between 70 and $80 \%$ had either cohabited or married (Kiernan 2002b, fig 5.2).

Life was not completely bleak, however. Italian men and women who had never married or cohabited were the most likely of any in the FFS survey to be having an 'intimate relationship' with a person living in a different household - 50 and 58\% respectively of man and women aged 25-29. In Spain, the comparable figures were $45 \%$ and $38 \%$; most of the other countries in the surveys reported figures between 30 and $40 \%$. However these answers do not tell us what proportion were 'living apart together' in the sense discussed below.

What has been the net result of this in terms of the beginning of partnership? Taking just marriage by itself, of course, modern partnership is several years later than in the past, and increasing in all places all the time. If we take into account cohabitation, which mostly occurs before marriage or is a preliminary to it, a different pattern emerges. Table 4.3 below shows the median age at the beginning of the first co-residential partnership in a variety of European countries in the early 1990s.

Table 3. Median age at first partnership, females, selected FFS countries 1990s

\begin{tabular}{llllllllllll}
\hline & \multicolumn{3}{c}{ Estonia Latvia } & France & \multicolumn{3}{c}{ Italy } & \multicolumn{3}{c}{ Lithuania Norway Spain Sweden Belgium $\begin{array}{c}\text { Nether- } \\
\text { lands }\end{array}$} \\
birth cohort & & 1995 & 1994 & $1995-96$ & $1994-5$ & 1988 & 1995 & $1992-3$ & $1991-2$ & 1993 \\
\hline late 1960s & 21.1 & 20.0 & 21.0 & $(25+)$ & 20.7 & & 23.6 & 20 & & 21.7 \\
early 1960s & 20.7 & 20.3 & 20.5 & 24.4 & 21.7 & 21.6 & 22.9 & 19.9 & 21.5 & 21.6 \\
late 1950s & 21.4 & 20.5 & 19.8 & 23.4 & 21.5 & 21.6 & 21.8 & 19.4 & 20.7 & 20.8 \\
early 1950s & 21.6 & 20.7 & 20.6 & 22.5 & 21.9 & 21.7 & 22.4 & 19.6 & 20.5 & 20.8 \\
late 1940s & 22.6 & 21.2 & 20.4 & 23.1 & 21.8 & 22.1 & 22.6 & 20.3 & & \\
\hline
\end{tabular}

Note: definition of birth cohorts varies between surveys and is approximate Source: computed from FFS Standard Country Reports table 8 or 8 a. UN ECE Economic Studies no 10.

In much of Europe the age when young people first begin living together, whether married or not, has been, in most cases several years younger than the mean age at marriage. In much of Europe in the 1990s, 21-22 was a more normal median age for young women to begin living with a man, about 4 years earlier than mean age at first marriage at that time. However, in more recent birth cohorts, median age at partnership increased slightly. Figure 4.6 shows that in a variety of countries, that age had risen to over 22 years for women and over 24 for men. Many of these early relationships will not endure, of course, as the section below indicates. In Great Britain the median age at marriage rose from 22 in 1958 to 27 in 1998, while the median age of the commencement of the pre-marital cohabitation that preceded it had risen from 21 to 23 (Haskey 2001, Figure 7). That did not, however, include any prior episodes of cohabitation. 


\section{Stable, informal unions?}

Cohabitation, evidently, is very popular. Staying cohabited is not. Other things being equal, cohabiting unions break up much more frequently than do married unions and last for a shorter time. This is evident wherever the question has been studied: in Sweden (Hoem and Hoem 1992), in the Netherlands (Klijzing 1992), in France (Toulemon 1996), in the United Kingdom (Haskey 1999) and in the United States (Teachman, Thomas and Paasch 1991), for example. The additional risk of dissolution has varied from 1.5 times (former East Germany) to five times greater (Norway and Switzerland; Kiernan 2002a). How short they last is not always easy to measure: cohabitation can end by separation, by the marriage of the partners or alternatively can still be in being at the time of the survey. Among women aged 20-39, those ending in marriage have typically lasted about 20 months in most West European countries. Those ending by separation were somewhat longer-lasting, between 30 and 50 months in most countries (those in Britain and Norway are particularly transient, at 19 months). The median duration of cohabitations in the 1990s was about 3 years; about 4 years in France and Sweden, just over two in Britain, in Switzerland, Norway and Finland (Kiernan 1999 table 6 , table 7). Marriages of women aged 20-39 were roughly three times as likely to survive over a given time than cohabitations; the contrast being the least in France and the greatest in Britain (Haskey 1999) and Switzerland. In Britain where $70 \%$ of first unions in the 1990s were non-marital, 29\% of cohabitations ended each year; 18\% turning into marriage, $11 \%$ dissolving the partnership altogether (Ermisch and Francesoni 2000). Children do not mitigate these high risks. In fact in Britain, where $22 \%$ of births in the late 1990 s were in such unions, fertile cohabitations were less likely to be converted into marriage and more likely just to break up (65\%) than were childless ones (ibid.), turning a partner into a lone parent.

Some empirical evidence from the US, however, suggests that the characteristics of cohabitation make it intrinsically more fragile: in cohabitation there is less pooling of resources, a greater assumption of financial autonomy by each partner, less agreement on the figure or the relationship (Blumstein and Schwartz 1983) except insofar as it is expected to be transient, as many of the studies above have shown. In other words, transience follow naturally from some of the reasons why it was preferred to marriage in the first place, and from the kind of people that prefer it.

The British Millennium Cohort Study has shown that relative impoverishment and fragility remain characteristic of unmarried families. Cohabiting families with young children tend to be more fragile, vulnerable and impoverished than their married counterparts. Single mothers and their children are least favoured of all. $25 \%$ of children born to cohabiting parents were no longer living with both these parents when they were 5 years old compared with 9 per cent of those born to married parents. Change of status from cohabiting to married tended to improve family circumstances, transition from cohabiting to lone parent to worsen it (Holmes and Kiernan 2010). 
Similar connections are reported elsewhere, for example the United States (Manning and Brown 2006) although the supposed harmful effects are more nuanced. Poverty lies behind much of this behaviour, and it underwrites the continuation of poverty into the next generation (McLanahan and Percheski 2008).

Cohabitation, when not viewed as a substitute for marriage, is often considered to be a desirable preliminary to marriage that enables the partners to test their suitability without damaging personal or financial commitment. Those less suited are 'weeded out' and break up; those better suited continue cohabiting or get married. In Sweden the moral pendulum is claimed to have swung so far that it is considered to be irresponsible to marry without having cohabited first. In Britain, too, a majority of men and women under 55 would advise young people to cohabit before marrying (Haskey 2001, Figure 2). It was rather surprising, therefore, to find that marriages following the cohabitation of the same partners were more prone to divorce, not less: in Great Britain (Haskey 1992; Berrington and Diamond 2000); the USA (Lillard, Brien and Waite 1995); Australia (Bracher et al. 1993) and even Sweden (Trussel et al. 1992). Could it be that those less inclined to commitment would choose cohabitation and would thereby be less likely to commit themselves fully to a marriage? It might also be that those who choose cohabitation first are self-selected in other ways, with characteristics - poor finances, ill matched personalities, that make dissolution of any kind of union more likely. Or the experience of cohabitation might itself change attitudes against the permanence of marriage. Most evidence appears to support the 'selection' idea, which predicts the lower stability of the marriages of former cohabitors and the lower stability of cohabitations (Dourleijn and Liefbroer 2002). However the facts are uneven; not only did the relative risks differ twofold between countries but in some there seemed to be no additional risk at all (Kiernan 2002a).

The notion of selectivity, however, suggests that the sharp distinctions between cohabitors compared with those who choose marriage first should diminish as cohabitation becomes more prevalent in the society and, at the same time, more socially accepted. Innovators prone to accept new ideas and behaviour, and from whom new ideas diffuse, are often highly atypical of the rest of society; while those who may gradually come to accept new ideas practiced by others occupy a more middle ground. With cohabitation 'normal', while 'weeding' will continue to make cohabitation less stable than marriage, there should be no more selection to make marriage after cohabitation more fragile than marriages that began without it. At the other end of the scale, once premarital cohabitation becomes usual, the minority who resist it (for example fundamentalist followers of religion in a secular society) may become themselves more and more selected and atypical of fellow citizens. Results from 16 European countries - East and West - that corrected for other risk factors such as education, employment and background, suggested that is happening: dissolution rates of different types of unions tend to converge when about half the population has experienced cohabitation 
and show the greatest differences when cohabitation is either practiced only by a minority, or by a substantial majority, of the population (Dourleijn and Liefbroer 2002).

\section{Cohabitation - one word, many meanings}

How are we, then, to understand cohabitation? It is obvious that people in different parts of Europe are behaving in very contrasting ways and treating cohabitation rather differently, with a big North / South divide. In southern Europe, family ties remain strong and pervasive, while this 'familism' is much less marked in Northern Europe where family ties are weak, families less patriarchal and society less based on kinship (Reher 1998). In Southern Europe cohabitation remains less common, though increasing and is usually a preliminary to marriage, not an alternative to it, favoured more by Northern, urban populations. The Dutch and Germans adopt cohabitation very widely, but usually as a preliminary to marriage. While many children are born to cohabiting unions, the partners often then marry and births outside marriage are not (yet) the norm. Those countries, then, have lower rates of birth outside marriage than might be suggested by the cohabitation figures, although in the late 1990s, unmarried motherhood in the Netherlands increased rapidly. In Britain, France, Austria and in Scandinavia cohabitation is now the usual way of beginning a union, seen as an alternative to marriage and by many as in no way inferior to it - a natural setting for the birth of the couple's children (Perelli-Harris et al. 2012). In those countries $40-50 \%$ of births are outside marriage, mostly to cohabiting unions. In the UK and in the Irish Republic (and the US) however, there are many more births to lone mothers. Although cohabitation is a more transient affair than marriage, sometimes repeated, it is clearly here to stay.

Will cohabitation displace marriage over all Europe, to the same degree as in Scandinavia, or even further? Trends suggest a progression, and the meaning of cohabitation has developed over time (Manting 1996). In most of Europe outside Sweden and Iceland, cohabitation used to be a refuge of the poor underclass and the boast of isolated Bohemians. Later it became a self-conscious lifestyle statement of the progressive intelligentsia, especially in the low countries in the 1960s and 1970s. A small number of cohabitants, often of higher educational and social status, were the vanguard of broader fashion from deviance to social acceptance, while marriage became an option across all classes (Ermisch and Francesconi 2000). Once established it is handed on between generations - children brought up in cohabiting unions or lone-parent families tend to regard that as the preferable norm. But clearly a wider explanation is needed. The social, welfare and political environment needs to be propitious; second demographic transition theory, discussed below, suggests how most of Europe became receptive to such non-traditional ideas. Those populations where cohabitation has become 'normalised' usually moved through stages over time, similar to the positions occupied by societies today where cohabitation is still not the norm - cohabitation mostly as a pre-marital preliminary, most births still within marriage. But as far away as Japan (Raymo, Iwasawa and Bumpass 2008), those societies are changing. 


\section{Divorce and separation}

The lawful termination of marriage remained relatively rare and inaccessible to most people in Western Europe until well into the $20^{\text {th }}$ century. As a 'demographic' variable, it is unique in that it is defined by law, not by biology. Hence, in part, its huge variability over time and space. Indeed, its legal definition can make it a poor indicator of what really interests us; the breakdown of relationships. Absence of easy divorce keeps officially alive relationships that have become shells; but easy access to it may facilitate the dissolution of unions that otherwise might survive. Naturally divorce tells us nothing about the dissolution of unofficial unions.

In many countries, however, marriages before the $20^{\text {th }}$ century lasted no longer (about 15 years) than they do today, except that the loved one departed in a coffin rather than in the divorce courts. Up to the early $20^{\text {th }}$ century, remarriage - following widowhood - was common. Indeed divorce has been described as a functional substitute for death. Of course informal ways were found round the ties of marriage; desertion was not infrequent; in rural England celebrated but actually uncommon 'wife sales' were known (Menefee 1981). Where the Church of Rome was dominant, annulment of marriage was possible and at least in earlier times, the canonical grounds for granting it appear not to have been abused as much as some suppose (Phillips 1988). Paradoxically, in England, where the reformation was invented in order to facilitate a Royal divorce, the new regime made the formal dissolution of marriage almost impossible for over three hundred years.

With the broad long-term social changes from the $19^{\text {th }}$ century onwards (Lesthaeghe 1983) women's rights in marriage, as in wider society, began to creep towards equality, and with them the right to divorce on equal grounds to husbands and to protect their own property. In countries where divorce was hitherto rare, it became merely infrequent, if still usually scandalous. In some countries where it was formerly prohibited it became legalised, as in Portugal in 1920, always the most socially revolutionary of the Southern European countries. Despite that innovation divorce there remained at a very low level until the late 1980s. In post-war Europe legal and welfare changes facilitating divorce have provoked inevitably sharp, discontinuous increases in divorce rates that are very apparent (see also Council of Europe 2003, Figure G2.6, 63-64). Social change, especially the achievement of more equality and political power by women created a demand for divorce reform, usually provoking a spike of new divorces, in between which rates creep up. While both world wars provoked a rash of divorces, for obvious reasons, the interwar and post-war years were a golden age of marital stability, never seen before or since. In most European countries, less than one in ten marriages solemnised in the 1930s and early 1950s ended in divorce and their average duration was over a quarter of a century. Remarriages accordingly fell to the lowest level ever. In some countries divorce simply did not exist, in Italy until 1974 (following a referendum), in Spain until 1981 in the Irish Republic until 1996. 
From this low level, divorce has increased in all regions of Europe up to the present, although to a very uneven degree. This was aided by the reforms of divorce law that were general across Europe in the 1970s, introducing 'no-fault' divorce, divorce by mutual consent and facilitating access to divorce through legal aid. In some countries the reforms clearly caused substantial and irreversible increases in divorce and established perverse incentives that encouraged breakdown (Dnes and Rowthorn 2002). In many countries the duration of marriage to divorce has halved, from about 8 years to 4 , with the peak year usually being the earliest at which divorce is legally possible. Modern married couples divorce as soon as they can. In general the geographical progression of higher divorce rates from the 1960s resembles the geographical pattern of the retreat from marriage over the same period. Divorce rates in the Scandinavian countries rose first and fastest.

One conventional way of representing the impact of divorce rates on marriage is to calculate a 'Total Divorce Rate' by summing the age-specific divorce rates based on the total population by age of each sex (Figure 4.6a, 4.6b). That measure, analogous to the total fertility rate and the total first marriage rate, yields the total number of divorces that the average person could expect to experience, conventionally up to age 50, given the continuation of current rates. It gives a rough picture of the implication of those rates for marital failure without having to wait for the experiences of real cohorts to unfold. Thus by the mid-1970s, total divorce rates in Scandinavian countries had risen from about 0.12 in 1960 to about 0.35 - implying, not very accurately, that given those rates, one in three marriages would end in divorce by age 50. That risk was not reached in Western Europe as a whole until the mid-1990s. At the beginning of the $21^{\text {st }}$ century, total divorce rates in Western Europe varied between 0.3 and 0.4 . This indicator has the big disadvantage that it does not relate the risk to the married population, only the total population. At the least it gives a measure of the prevalence of divorce overall. In the absence of generally available life-table based measures it is the best that can be offered for most countries.

In the Southern Catholic countries in Europe (with, as usual, the exception of Portugal), restrictive legislation kept divorce absent or infrequent. Although trends are upwards, relative liberalisation of divorce law has not provoked a rush to divorce in the Southern countries. The Protestant and Orthodox traditions of Northern and Eastern Europe have always been more tolerant of divorce than has Catholic culture. That is one reason why divorce rates in Northern and Eastern countries (including Greece) have been historically higher, accelerated in the latter case by decades of communism. In the former communist countries, divorce, like abortion, was generally readily accessible and prevalent, partly for ideological reasons as part of a strategy to minimize the obstacles between the State and the individual, also out of hostility to its traditionally religious setting. The Soviet Union used to have the highest divorce rates in Europe - 0.34 in 1970, when elsewhere they were relatively low. Interestingly, though, divorce rates in the Central and Eastern European countries never rose above about 0.25 on average during the whole of the communist period. 


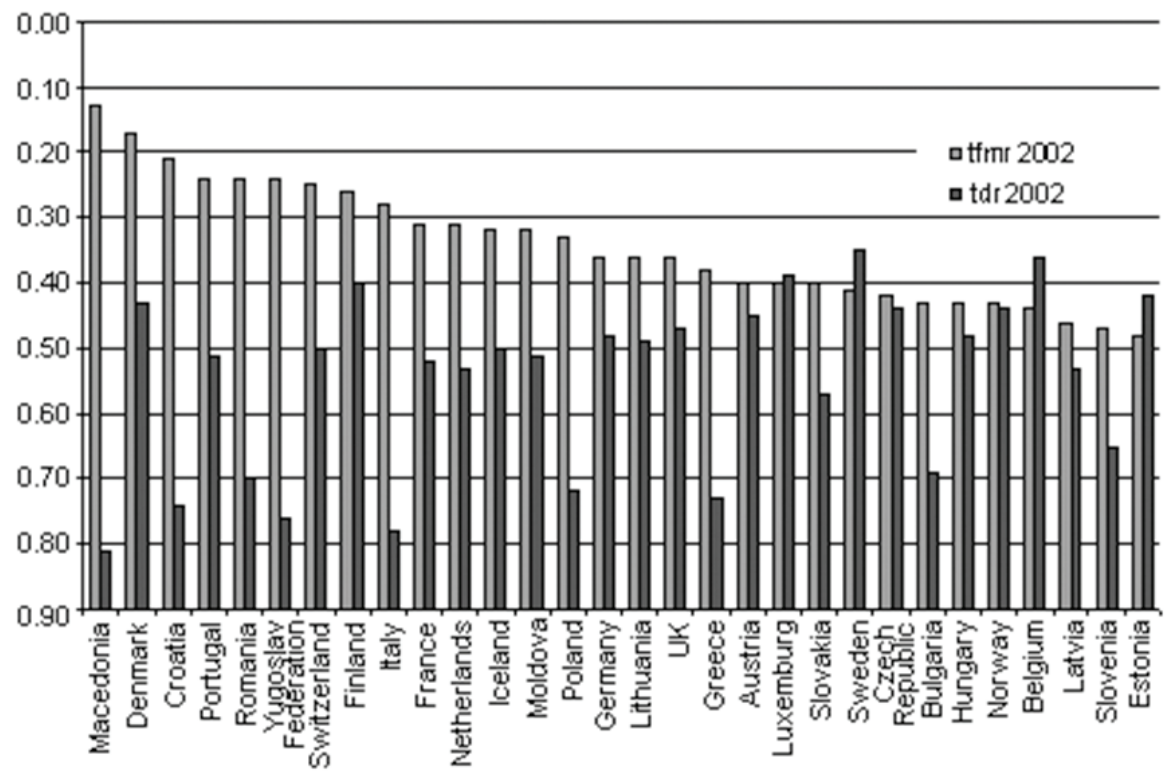

Figure 5. Total First Marriage Rate and Total Divorce Rate, 2002. European countries, arranged in descending order of TFMR. Source of data: Eurostat.

Stasis, as usual, was the rule. Since then, marriage has become most fragile in some of the more 'Western' countries (e,g, Hungary) and also in the Czech Republic, where it was always high. For reasons discussed elsewhere, and not intentionally, communist policy made marriage the essential key to household, privacy and housing, benefits not lightly set asunder. It seems that this legacy persists in some countries even in the postcommunist turmoil. Divorce rates in Romania in 2002 were the same - about 0.20 - as in 1960, in Bulgaria and Poland were unchanged -0.21 and 0.18 respectively - since 1985, And in former Yugoslavia remained even lower up to 2002. Between 1970 and 1990 divorce rates in the (formerly Soviet) Baltic States, high since the 1960s (TDRs cannot be computed before about that time), were the highest anywhere - often over 0.5 -and have even declined since. Despite that decline, the divorce rate in Estonia in 2002, uniquely with Sweden and Belgium in the developed world, was higher than the marriage rate (Figure 4.5)

For a few countries only, divorce rates based on the currently married population can be calculated according to life-table methods. Because these are based on the population actually at risk, a more accurate evaluation of the risk facing marriage relative to the duration of marriage can be made, not to the age of either partner. For example, since the 1970s, divorce rates in the US on an actuarial basis have been equivalent, to the dissolution of over $50 \%$ of marriages before their $25^{\text {th }}$ anniversary taking the effects of mortality and of divorce together ('gross divorciality'); up to the $25^{\text {th }}$ anniversary, divorce is by far the more important factor. 'Net divorciality' measures solely the 
effects of divorce. Europe is now busy catching up. In the United Kingdom, divorce rates in 1994 were equivalent to the dissolution of $38 \%$ of marriages by the $25^{\text {th }}$ anniversary (Haskey 1996), and 53\% through the combined effects of divorce and death. The expectation of life of the marriage was then 26 years. Ten years later the former probability had risen to $42 \%$.

Is there any reason why these trends should not go on increasing? There is no technical reason why all marriages should not end in divorce and therefore why total divorce rates should not approach one, or even exceed it if the average person marries more than once. In a few countries TDR has already exceeded 0.5. However, as Figure $6 \mathrm{~b}$ shows, in some populations, for example Denmark, France, Norway, the increase of divorce rates appears to be flattening out.

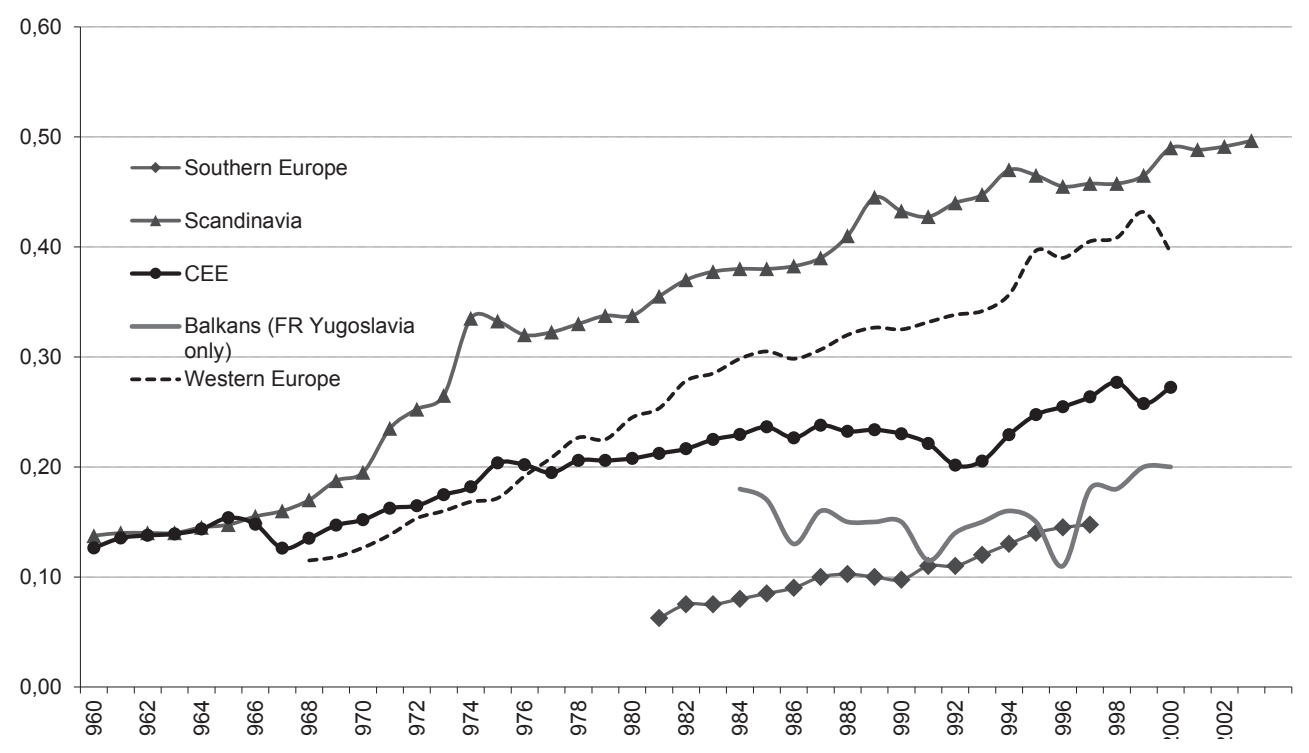

Figure 6a. Total Divorce Rate, groups of European countries

In part, this is a result of the diminution of the proportions married, so that married couples are a more selected sample, and the later age at marriage, which other things being equal reduces the risk of dissolution. At the time of writing, total divorce rates are not conveniently available after 2002 for most European countries. Trends for Austria, the Czech Republic, Latvia and Switzerland are shown to 2011, could be stabilising at just under 0.5 . 


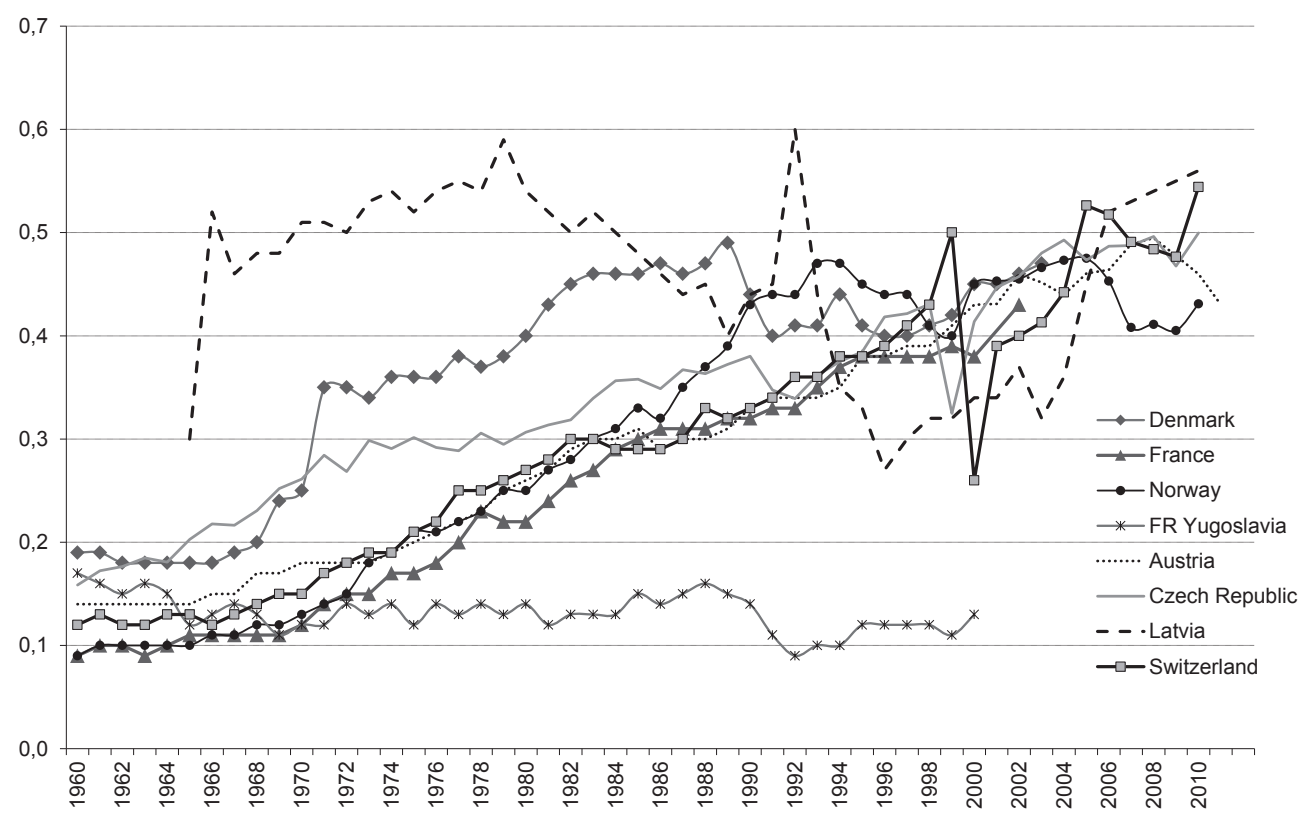

Figure 6b. Trends in total divorce rates, selected European countries 1960-2011

\section{Living apart together (LAT)}

Many people in sexual relationships who consider themselves to be a 'couple' do not live together cohabiting or married but instead 'live apart together' that is, they retain their separate homes, mostly during the week, and at least some separate property but live together in one or other residence on a regular basis, usually at weekends. This tactic is known throughout the industrial word, not excepting Korea and Japan. An old practice among a minority of the married and divorced, it is, like cohabitation, a relatively novel form of behaviour for the young and single, only attracting the attention of demographers from the 1980s, having first been described in its modern form by a Dutch journalist (Levin and Trost 1999). Married couples may live this way, indeed many will have had to over the centuries. Migrant workers who leave their families in remote towns or even foreign countries are an extreme example, perhaps. In our own time many professional married (but usually childless) couples perforce adapt this way of life when their careers lead them to take posts too remote from each other for daily commuting. When both partners have professional or high-paid careers, promotion or a career move for one can only be accepted at the cost of separation.

Others adopt a modified form of it when (usually the husband) commutes weekly to a metropolitan job returning to wife and children in the family home, perhaps in a small commuter town or rural village, at weekends. Manual workers whose skills are in short supply in big cities may be unwilling to move there or be unable to afford a 
permanent family home there, and commute weekly. Thus bricklayers from Newcastle travel weekly to London, 250 miles away. These, however, are usually regarded as undesirable distortions made necessary by the pursuit of a career and a high salary, or by unbridgeable differentials in house prices. They are better described as a 'commuting marriage', as each partner does not have an independent, equivalent establishment of their own. That is what makes the difference.

More interesting is when couples, usually unmarried, who may live or work relatively close to each other, nonetheless choose this semi-detached approach to love. In some European countries, this way of living may have become even more common than cohabitation. For example in a sample of people aged 18-61 in Germany in 1994, 9\% were living apart together (Schneider 1996, cited in Levin and Trost 1999) and $8 \%$ cohabiting, in France in the same year the figure was 6\% (Caradec 1996) and in Norway $1996,8 \%$ of adults. Another French study indicated that in $1994,7 \%$ of unmarried couples and $2 \%$ of married couples reported that they did not share the same address, a position not much changed since the 1980s (Villeneuve-Gokalp 1997). However, in some of these studies a variety of ways of life may be bundled together in the responses. A careful study in Sweden suggested that 2\% of adults aged 18-74 in 1998 were in LAT relationships strictly defined (Levin and Trost 1999).

In Southern Europe, LAT seems to be an idea for which the local populations, or perhaps just their demographers, are not yet prepared. English-speaking populations seem to be keen on LAT; in $20018 \%$ of the Canadian population aged 20 or over were in LAT relationships. 25\% were over age 40 (Milan and Peters 2003). In England and Wales in 2002-3, the official Omnibus survey found that, overall, just as many people were living in LAT relationships as were cohabiting: about $24 \%$ of unmarried and men, and $26 \%$ of women (Haskey 2005). It was the overwhelmingly most prevalent from of association for teenagers and people in their lower 20s: $26 \%$ of all 16-19-year-old men were living apart together, and 35\% of women. Among people aged 16-24, LAT was about four times more prevalent than cohabitation among young men, and about three times as prevalent among women.

The modal age-group was 20-24 in both sexes, about ten years younger than cohabiting couples. About $5 \%$ were same-sex couples. A high proportion - about one in three women, $40 \%$ of men, were still living (most of the time) in parental homes. A third of men lived alone and a fifth of women, three quarters were single, about 1 in 9 men, and 1 in 5 women, were divorced - about half the proportion among cohabiting couples. For the most part, LAT relationships were short term - the median duration in this sample was 1.5 years, compared to 5-6 years for those cohabiting in the same sample. The usual age difference between the couple was absent, suggesting that many were individuals who had formed relationships with partners first encountered in the same co-educational school or college. 
Taking account of LAT brings down the average age of partnership in European countries to an even lower level than does the inclusion of cohabitation into the equation. In Britain it increases the proportion of teenagers in 'partnerships' to about half, and $2 / 3$ of men and women in their early 20s. LAT and cohabitation overlap; either one can lead to the other.

Some, especially those who can each afford to maintain their own establishment, may prefer a more arms-length relationship even if cohabitation or marriage would be possible for them. Older people may find that easier to continue caring for parents or keeping in close touch with children or grandchildren. Others may be fearful of making the same mistakes in a co-residential union that lead to previous failure. Older people may find LAT convenient, particularly those bruised by earlier failures of marriage and cohabitation and who do not want to repeat the complications of separation. In the Netherlands, for example, the over-50s prefer cohabitation and LAT over remarriage for such reasons, although with mixed results - social networks expand, but contacts with children suffer (Gierveld and Peeters 2003). Among the increasingly vigorous and sexually active over-sixties, it also serves as an escape route from the potential risk of caring for a partner who may, in a few years, descend into dependency or for whom Dr Alzheimer calls early. Nonetheless Gierveld and Peeters conclude that stress and financial insecurity underwrite this phenomenon.

For many young unmarried people, LAT is a product of the same relaxation of norms that has enabled cohabitation to become so common. In the past, what can now develop into LAT would have stopped at the stage of 'going steady' or 'engagement'; the partners would simply not have been able to slip off somewhere else at weekends. Indeed, some insist that LAT could not have arisen without the prior acceptance of the institution of cohabitation (Levin 2004).

Europeans never lack ingenuity in devising new ways of combining companionship and sex with convenience, work and independence and the avoidance of commitment.

\section{Births outside marriage}

As marriage retreats, reproduction continues without it. The increase in the proportion of births outside marriage is one of the most statistically dramatic developments in Europe in the last fifty years. Increasing from negligible proportions in the 1950s, in some countries there are now more births outside marriage than inside it (Figure 4.7a, 4.7b). Marital births have diminished as marriage diminishes, and the changing ratio reflects that fall as well as an absolute increase in births outside marriage. Overall, of course, total fertility has fallen by about $25 \%$ since the 1970 s.

Like so many of the developments of the late $20^{\text {th }}$ century, this is a unique new pattern. Only in a few populations, created by slavery or the more oppressive forms of 
colonisation, such as the blacks of the US, the populations of the West Indies and some Latin American countries, have these rates been exceeded (Therborn 2004). The pattern between and within countries is very variable. Legitimate births are still the norm in the countries of Southern Europe - the same ones which have low levels of fertility, divorce and cohabitation. Elsewhere, a birth outside marriage is the normal life experience of couples from all parts of society, many of whom will later marry (Table 4). Thus among women in Sweden aged 20-29 who were in partnerships, 91\% who had no children were cohabiting, and $89 \%$ of those who had children. The latter proportion fell sharply in older age groups in most of the countries under discussion. Cohabiting couples with children were less common in southern Europe - but still $30 \%$ of partnerships of younger women were of this type in Spain and Portugal, much less so in Italy, none in Greece.

Table 4. Percent of all partnerships that were cohabiting partnerships, not married partnerships, European countries 2007. Source: Eurostat.

\begin{tabular}{|c|c|c|c|c|}
\hline & \multicolumn{2}{|c|}{$20-29$} & \multicolumn{2}{|c|}{$30-39$} \\
\hline & No children & Children & No children & Children \\
\hline Sweden & 91 & 69 & 82 & 44 \\
\hline Estonia & 77 & 54 & 75 & 36 \\
\hline Denmark & 82 & 52 & 62 & 22 \\
\hline Ireland & 67 & 51 & 37 & 9 \\
\hline France & 79 & 47 & 62 & 31 \\
\hline Belgium & 68 & 45 & 45 & 19 \\
\hline Finland & 81 & 45 & 61 & 23 \\
\hline United Kingdom & 65 & 41 & 38 & 20 \\
\hline Slovenia & 65 & 37 & 45 & 23 \\
\hline Netherlands & 86 & 34 & 60 & 24 \\
\hline Portugal & 39 & 30 & 29 & 8 \\
\hline Spain & 52 & 30 & 27 & 9 \\
\hline Latvia & 52 & 29 & 58 & 15 \\
\hline Austria & 55 & 25 & 47 & 10 \\
\hline Hungary & 57 & 24 & 50 & 12 \\
\hline Czech Republic & 58 & 22 & 42 & 9 \\
\hline Germany & 64 & 19 & 41 & 7 \\
\hline Luxembourg & 59 & 19 & 26 & 9 \\
\hline Italy & 22 & 17 & 23 & 7 \\
\hline Lithuania & 46 & 12 & 27 & 7 \\
\hline Poland & 26 & 7 & 11 & 2 \\
\hline Slovakia & 18 & 5 & 23 & 4 \\
\hline Cyprus & 33 & 2 & 15 & 1 \\
\hline Greece & 25 & 0 & 7 & 0 \\
\hline EU-25 & 63 & 28 & 38 & 14 \\
\hline EU-15 & 66 & 33 & 39 & 16 \\
\hline
\end{tabular}

Data:

http://epp.eurostat.ec.europa.eu/cache/ITY_OFFPUB/KS-31-10-555/EN/KS-31-10-555-EN.PDF 


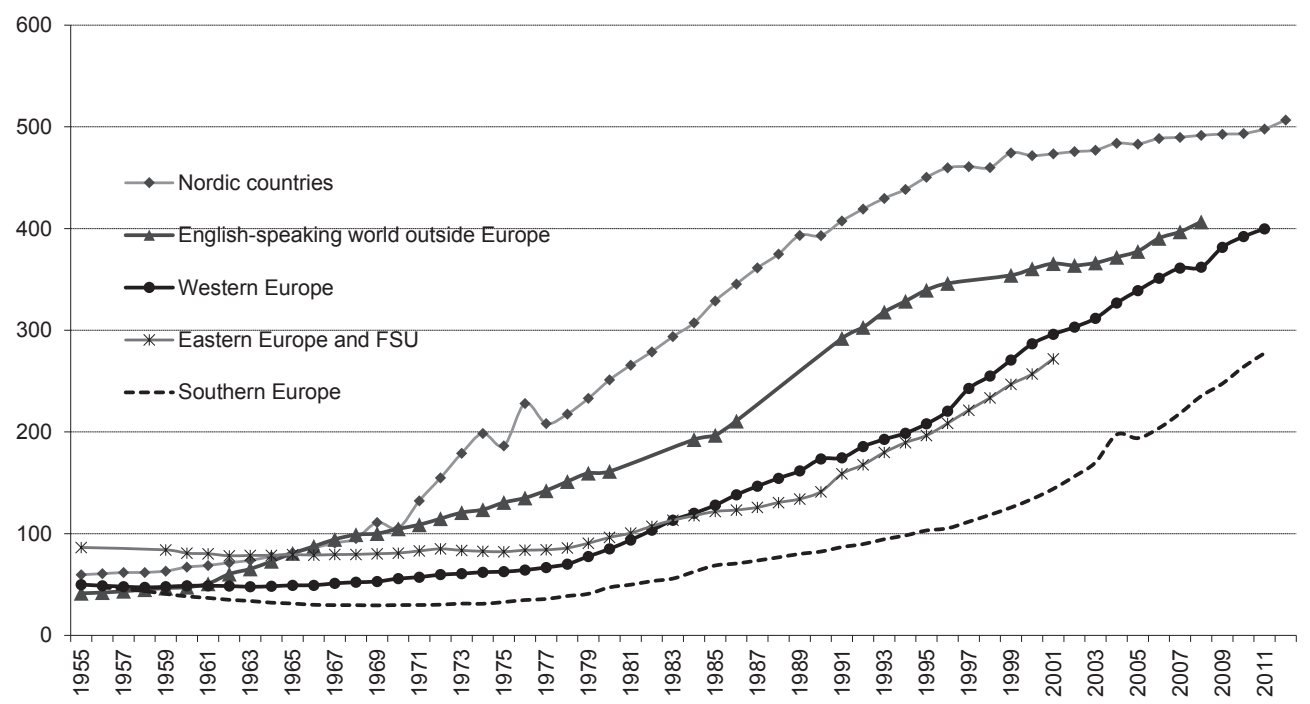

Figure 7a. Trends in proportion of births outside marriage, European regions

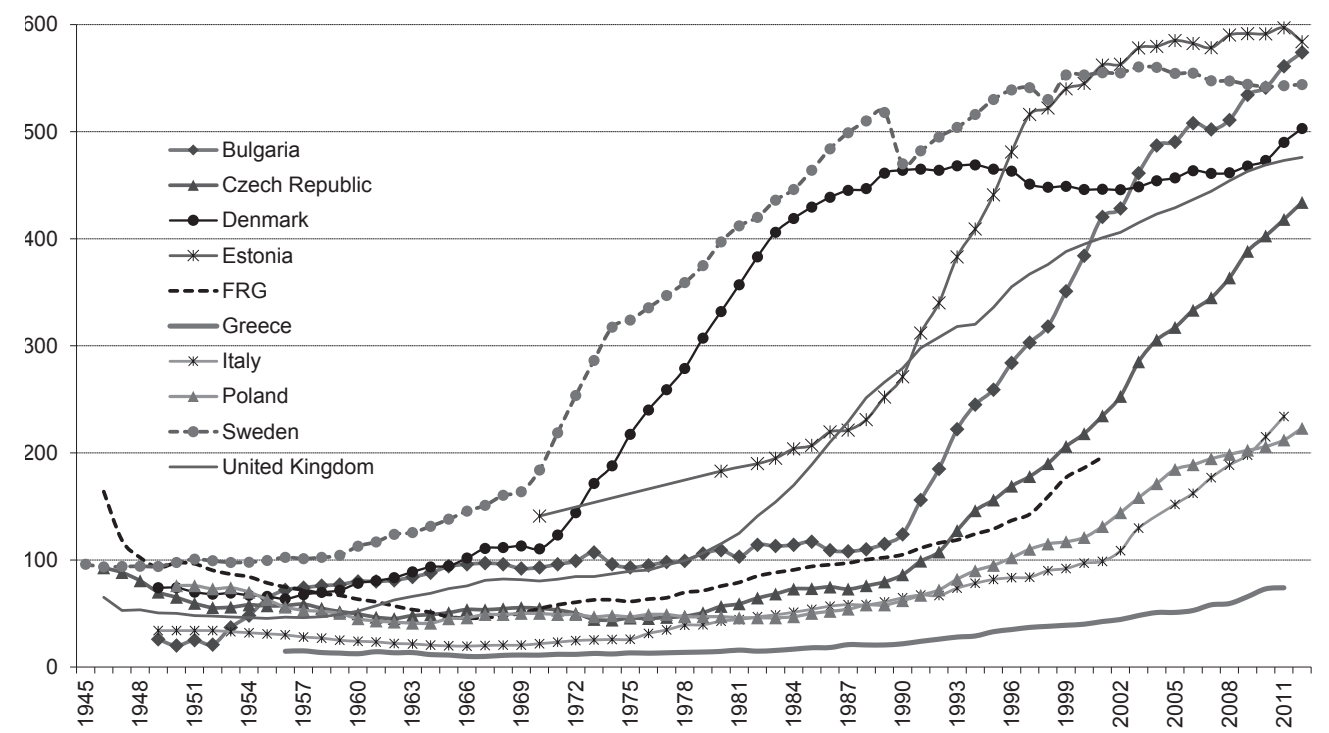

Figure $\mathbf{7 b}$. Trends in the proportion of births outside marriage, selected countries.

The diversity within Europe follows a geographical pattern now familiar. In general, since the 1960s the Scandinavian countries have had the highest proportions. By about 2010 that might have been levelling off, with about $50 \%$ of births still inside marriage, $50 \%$ outside. Data from Iceland are not included in the graph - even in 1949 31\% of births there were outside marriage. Births outside marriage in 'Western' Europe - that is, the 10 countries not in Scandinavia or Southern Europe - rose on average from 
$5 \%$ to nearly $30 \%$. The CEE and former Soviet countries together had the highest proportions of births outside marriage in the 1950s. After the late 1970s they shared, on average, a surprisingly similar trend as Western Europe. But that average conceals great diversity: relatively modest increases in Poland; a radical discontinuity of trend in Romania, Bulgaria, Estonia and other countries (Figure 7b) These sharp increases in proportions of births outside marriage are driven by an overall collapse in the birth rate, particularly births to married couples, while births outside marriage remained high in groups where this was traditional, or increased somewhat. By about 2010 the average in the southern European countries, previously low, had accelerated to reach almost $30 \%$.

The relationship with cohabitation is very varied. In Germany, Austria and the US, for example, cohabitation is common but births outside marriage within cohabiting unions less frequent. In the Scandinavian countries, in France and in the former East Germany, one follows from the other. In Britain, a different and more pathological pattern prevails (Coleman and Chandola 1999) - over a third of births outside marriage are to women without any partner, either married or cohabiting; a pattern found elsewhere only in the United States and in some of the Eastern European countries still in the anomic grip of post-Soviet turmoil. In Scandinavia there is little differentiation on class lines, but in the UK the experience in more sharply demarcated. There, childbearing outside marriage is still much more common among the children of non-manual workers, often unemployed, residents of 'social' housing and certain immigrant minorities. Teenage childbearing, almost all outside marriage and mostly unpartnered, has been the highest in Western Europe since the 1960s. In England and Wales, births per 1000 women under age 20 had been steady at about 30 for some decades, but since then the rate has fallen to reach 19.9 in 2012.

\section{Explaining living arrangements and their trend}

Attempts to account for patterns in living arrangements over space and time are inevitably pitched at rather a general level. We have several 'demographic' variables to account for, changing more or less in unison over a space of a few decades, but at a very different level between countries. These are strongly related to other significant parallel changes in society: some causes, some consequences. These include greater wealth, (usually) more equality between the sexes, the advance of education, especially of women, the evolution of workforces from agricultural to industrial and from industrial to service, with much greater involvement of women, much smaller families, the decline of religion and traditional values in general. In short, in trying to account for the transformations described above, we are at risk of trying to explain much of the modern world, of which demographic patterns are a reflection. As usual in demography, accounts tend to divide themselves between the economic and the cultural and between the proximate and the more remote, although few of the categories are exclusive. 


\section{Economic models and economic effects}

Malthus was the first to emphasise in a systematic way the fundamental connection between income, subsidy, the timing of marriage and children, and poverty. The modern economic models presented to account for the fertility changes by Becker (1981) and his followers have their application here as well. These operate against a background of regularities of long standing shared by most European societies, however advanced or traditional their living arrangements.

For example, in modern times throughout Europe, men and women with higher earnings, higher educational level and higher social status typically marry later than others. Individuals with higher incomes concentrate on their careers. Workers on lower incomes, with flatter earnings profiles, tend to marry - or form unions - earlier in life, having less to lose by delay. For women the opportunity cost of early marriage and childbearing is substantial unless partners, family or family policy give support. Men with higher incomes and social status are more likely to marry and their wives are less likely to work than poorer workers. In the past, men typically married women of lower status than themselves. High status men were, and remain more likely to marry, while men at the bottom of the social hierarchy are more likely to remain unpartnered and childless (e.g. Barthold, Myrskylä and Jones 2012). Conversely most lower status women are married or in recent years more likely partnered, more of women at the top are not. With women approaching gender equality in the workplace, and possibly surpassing it in higher education, traditional patterns of union formation and partner choice will have to change.

Higher education postpones marriage and childbearing, less so cohabitation. Better educated individuals tend to marry later, therefore. Cohabitation, on the other hand, is more compatible with continued study and early career especially if childbearing is avoided. The great expansion of higher education, especially of women, throughout Europe is one of the most powerful factors behind postponement of marriage.

Given the equality or near-equality of women in law, property rights, education and employment, the former unequivocal advantages of marriage for women become less clear cut. With the traditional marital division of labour divorce was an extreme step because women could not easily support themselves or their family alone. Now, financial security is a matter of individual effort, not of finding or keeping a suitable partner. Hence the compromise of cohabitation becomes much more attractive where some of the consolations of the connubial life can be enjoyed without all the commitments. Similar considerations apply later in the life-course - divorce, though always painful, becomes less threatening to women because of the liberation of their financial independence through their own work. These effects, however, are seldom just one way. Work itself acts to heighten the chances of divorce in the first place, through financial independence and the chance of finding a better partner. Cohabitation with any new 
partner is the preferred option, especially if the marriage law is dysfunctional in not offering suitable protection to the partners (Dnes 2002).

In all European countries welfare arrangements take away some of the harmful consequences of lone parenthood and divorce but thereby also, at least in the economic sense, act as incentives. According to critics, those welfare arrangements discourage marriage (Morgan 2000) and even cohabitation, making lone parenthood a rational option for women dependent on welfare, especially those with low education and skills and few prospects. Reproduction outside marriage, and particularly outside any partnership, seems to be economically irrational but need not be so (Rosenzweig 1999; Willis 1999). Arrangements differ between countries. The German system is marriage oriented while in Britain the welfare system has often been claimed to encourage lone parenthood; so that poor employment opportunities encourage childbearing outside marriage and discourage the formation of cohabiting unions (Ermisch 2000, 29).

Higher-status men and women began the trend to cohabitation. Now, however, in some countries such as the UK, that is reversed - cohabitation is much more common, if not normal, among lower status and lower-income couples. The uncertainty of finances leads to caution about commitment. Male worklessness, and irregular employment, particularly associated with the end of traditional industrial work and the "male breadwinner' has been an important factor in the rise of cohabitation and reproduction outside marriage in Britain (Rowthorn and Webster 2008). Other considerations, apparently trivial, underlie the marginality of the decision among many couples whether to marry or cohabit. In the UK, marriage of poor partners may depend on the ability to spend lavishly on a proper white wedding. Failing that the couple will cohabit, at least until fortunes improve (Barlow and Duncan 2000). Furthermore, when low-status women without partners become pregnant they are much more likely now to cohabit than to marry (Berrington 2001). Costs are much less, continued access to welfare is assured by the absence of any official co-resident wage earner. Cohabiting women who are unemployed, in economic difficulty and have fathers in low skill jobs are more likely to have children while still cohabiting, rather than marrying (Ermisch and Francesconi 2000). Conversely women who are cohabiting are more likely to end their cohabitation by marrying if they or their partner are employed and are more likely to separate if they are not. The more the partner earns, the more likely they are to marry (ibid.).

In the past, only the well-off could divorce or pursue annulment proceedings. In modern societies where divorce is more universally accessible it tends to be the poorest, most economically marginal and least well educated whose marriages are most fragile, with divorce rather less common among professionals and the better-off. Financial instability is a direct and important contributor to marital argument and dissatisfaction; the negotiating skills of the better educated, and their greater inclination to develop a companionate marriage with shared interests, may also be important. Partners who 
were long acquainted, partners with similar backgrounds, partners with religious affiliation are also less likely to divorce. The single most important factor affecting the survival of marriage is age at marriage - the later, the better, at least up to age 40 or so. Late cohabitations also last longer (Haskey 1999), no doubt for the same reasons.

Childhood spent in a cohabiting union or a lone-parent family inclines individuals to adopt a similar life. Parental separation provokes earlier transitions and more instability in the later adult lives of the children: higher propensity to earlier union formation, cohabitation rather than marriage, earlier separation, earlier childbearing. Kiernan $(1992,2002 b)$ interprets this as a tactic to minimise the pain associated with disappointed commitment, escaping from a difficult home-life, in which friction with step-parents figures prominently. Such events contribute to the cycle of deprivation.

Religion divides those who favour the new life courses from those that avoid them. Throughout Europe, people with strong religious feelings are much more likely to choose traditional, rather than 'modern' life courses: to remain in the parental home rather than cohabit, to marry rather than live together, to have children inside rather than outside marriage, not to divorce (Berrington and Diamond 1999, 2000). If they do live together, then marriage takes place before, not after, the birth of children. In the 1970s, cohabitation was in some countries almost a badge of honour among the secular intelligentsia (Lesthaeghe 1996). Religious people, however liberal they may be in other matters, continue to reject that path, particularly avoiding births outside marriage and also being less prone to divorce.

\section{The Second Demographic Transition}

The architects of economic models do not deny the independent importance of values and culture but such notions do not fit their equations. The concept of the Second Demographic Transition (SDT) is the most comprehensive attempt to bring them all together on a broad canvas, to account for the parallel patterns and trends described above.

Today, the SDT is the mainstream concept that dominates demographic thinking on living arrangements in European societies. This ambitious model explains the substantial and unprecedented progress of cohabitation, lone parenthood, childbearing outside marriage and low fertility observed in many countries since the 1960s and the parallel retreat from marriage and from traditional norms of sexual restraint. As we have seen, all these demographic trends have been consolidated during recent decades and as the theory predicts, are increasing almost everywhere in the developed world, although still at different levels of prevalence (Lesthaeghe and Surkyn 2004).

The theory proposes that the new freedom of sexual behaviour, the diversity of forms of sexual partnership, and the relaxation of traditional norms and constraints observed in many Western societies since the 1960s, are intimately related and share common causes which are only indirectly economic. The new transition is made possible by parallel 
trends in further economic growth, intellectual emancipation through education and the concomitant ease of diffusion of ideas. The shifts in attitudes in younger cohorts are held to be irreversible and likely to become universal in developed societies as the attitudes diffuse geographically and as the post-materialist cohorts move up the age-structure.

On this view an educated and liberal-minded population, no longer limited by material anxieties, is able to emancipate itself from traditional rules and strictures, unconstrained by deference to religious authority or parental sanction. More concerned with 'selfrealisation' than with 'duty' or obedience to authority whether parental, civic, divine or customary, individuals choose modes of life suited to their convenience. Under these circumstances, the single state, cohabitation, lone motherhood and the avoidance of parenthood are more practical and feasible and become more socially acceptable. Conduct formerly frowned upon becomes tolerated or 'normal'. The spread of these 'post-material ' values in society, measured by questionnaire batteries, correlated with the spread of secular opinions, unconventional attitudes and toleration of behaviour formerly regarded as deviant, immoral or criminal.

The central position of the SDT has for the last decades been assumed in most modern demographic analysis (see, for example, the papers in Macura and Beets 2002). A 'syndrome' of Second Demographic Transition behaviour is evident: national populations with a high prevalence of (for example) divorce also tend to have lower levels of marriage, higher prevalence of cohabitation and of births outside marriage, and induced abortion ratios, although the statistical association using a straightforward correlation of simple indices is not always very strong. The trend towards 'post material' values and attitudes is sometimes presented by the votaries of the Second Demographic Transition as an historically inevitable universal development of irresistible force. However the identification of 'leader countries' which others follow has proved difficult; there does not seem to be one single trajectory (Therborn 2004). Liberating forces need not lead to convergence, unless all agree to be liberated in the same direction.

Low fertility (meaning fertility well below replacement level) is also claimed to be part of the SDT 'syndrome'. Logically few things could be more bound up with concepts of traditional duty, or attended with so much cost and inconvenience, as bearing and caring for children, and few things more liberating than to do without them. It would be reasonable to expect that populations that score highest on post-material ideational responses and which manifest strongly the other SDT attributes, should have the lowest fertility as well. But in general the reverse is true. On average, national populations most enthusiastic for non-traditional living arrangements within the developed world (North-West Europe and the Neo-Europes) tend to have the highest fertility, where the lowest might be expected. Populations with very low fertility are typically those where most fertility is confined to marriage (Billari and Kohler 2002; Balbo, Billari and Mills 2012). Thus all the countries of Southern Europe with the partial exception of Portugal, 
together with Germany, Japan, Korea and other developed countries outside Europe, have low or very low levels of divorce, cohabitation and births outside marriage while at the same time they have the lowest fertility rates in the world.

So far, the Second Demographic Transition theory seems to be leading to diversity more than transition. Only in few countries are more than half of all births outside marriage. In many populations, marriages are still more often ended by the death of one of the partners rather than by divorce. Especially in matters relating to family life, divergence rather than convergence is the striking cross-sectional pattern (Kuijsten 1996; Micheli 2000; Coleman 2002; Billari et al 2002, Billari and Kohler 2002), although some have insisted that its completion is simply a question of time (Roussel 1995).

On a larger scale the SDT remains regionally diversified. Trends have been upwards throughout Europe, as the graphs above show, although it is still more developed North of the Alps and widespread in the English-speaking world overseas. Asian immigrants and most of all Muslims within the Western world have remained notably resistant to the new modes of living despite (or perhaps because of) the example of the majority populations among whom they live.

Empirical trends in some SDT behaviour seemed to be levelling out by about 2010, as were noted above, with even some small indications of a recovery of marriage.

Cohabitation, divorce and births outside marriage are now prevalent in Central and Eastern Europe. After the fall of the communist system in 1989 many of these trends took off. That was widely interpreted as the evidence of the spread of the second demographic transition in the new Central and Eastern European freedom. That might fit in relation to the more prosperous, 'westernised' parts of the region (Sobotka, Zeman and Kantorova 2003; Lesthaeghe and Surkyn 2002), especially among the better off inhabitants of its great cities. Post-modern individualism is, however, by no means a uniform trend in the East; for example cohabitation in Poland is still usually a prelude to marriage (Fihel 2004); relatively few cohabiting couples have children.

Post-materialist theory does not make an appropriate model for the less prosperous sectors of the former Communist countries. It is difficult to see how post-materialist sensibilities, normally regarded as requiring for their nurture a secure material situation, could flourish in the serious economic downturn and heightened employment and political insecurity of the early post-communist period, and its continuation to the present in parts of the region. In some senses the restricted choices available in communist times went hand in hand with a high level of certainty and assurance about crucial life events - guaranteed education and employment, for example (Philipov and Dobritz 2003; Koytcheva and Philipov 2008). Communist society, with its certainties, might even have been a more fruitful environment for post-materialist views than was its uncharted aftermath (Kyveldis 2001). 
Apparently 'classical' SDT behaviour (e.g. high levels of births outside marriage) are unlikely to have been due to individual empowerment but to quite different, socially pathological, developments: the prevalence of 'anomie' and disorganisation among the poorer elements of the population distressed and unsettled by recent changes (Philipov 2001). The rapid increase of births outside marriage in Bulgaria and Romania, after over two decades of negligible change, are particularly noteworthy (Figure 4 ). These populations were among the poorest of the CEE countries under communism, are still substantially rural and have so far failed to make effective economic or political transitions, remaining in a weak economic position. All this can hardly be due to individual empowerment. Okolski (personal communication) notes that the highest levels of births outside marriage in Poland are found in rural areas of West Poland where most agriculture had been collectivised and where the collectives had all become bankrupt in the early 1990s. However, the difficulty of obtaining legal abortions in Poland may also be a factor. There, the populations were doubly detached from any conventional norms and restraints - once through the destruction of conventional village society (through collectivisation and transplantation from what is now Ukraine/ Belarus) and again when the collectives collapsed. Most of these births are to unmarried, poorly educated and non-cohabiting teenagers, not the target population of the enlightened, self-realising, secure concepts of the SDT.

Is the ideational change theory sufficient for a full explanation of the upward trends in divorce, cohabitation and the rest? Less ambitious, more conventional economic theories based on rational choice, not necessary contradictory to SDT theory, have also pointed out the drawbacks of conventional marital unions and the advantages of ambiguity when women are financially independent of men through their own work and as well, if not better, educated (Ermisch and Francesconi 2000). The empirically observable demographic trends charted above are, of course, indisputable. It is less clear, however, that they can all be swept up as evidence for the diffusion of ideas and attitudes specified by the SDT theory. A plurality of explanations may be more suitable, depending on circumstances. For example, is the continued high level of teenage childbearing, mostly to mothers without partners, observed since the 1970s in the UK and the US a component of the enlightened and self-realising behaviour envisaged by the SDT? Or is it instead, as both those government believe, harmful to the interests of mothers and children, against which policy measures are appropriate?

\section{Dangerous liaisons or lifestyle choice? The costs of the second demographic transition}

How much do these changes matter? The trends described above are usually presented in a neutral fashion. That is scientifically commendable. However autonomy, self-realisation and independence are regarded as uncontroversially advantageous. That may have distracted attention from some consequences of the new living and household arrangements. 


\section{Effects on children}

Inevitably, higher levels of union break-up, divorce and remarriage or re-partnering lead to children experiencing much higher levels of unconventional family backgrounds than earlier in the $20^{\text {th }}$ century, being brought up by one parent or with a step-parent. Across Europe, proportions of children in lone-parent families and reconstituted families are varied but generally high and increasing (Chapple 2009). At current rates it is expected that at least one in four children in Britain will experience life in different family forms (Haskey 2005).

The beneficial effects of marriage for men's health are well known compared with single, widowed and divorced men and are noted elsewhere, although little appears to be known in respect of long-term cohabitation except that is tends to relate to lower relationship satisfaction (Aarskaug, Keizer and Lappegard 2012). More important are the potential effects upon children. The association with poverty is clear, although the difficulties of attributing direct causal effects, and conflicting philosophical viewpoints, have kept this area controversial.

In the US white population, children in one-parent families, whether from divorce or single motherhood, are two to three times more likely to be classed as being in poverty than children in two-parent families; $30 \%$ of unmarried mothers remained in poverty; compared with $8 \%$ of married mothers (Lichter, Graefe and Brown 2003). The rise of lone-parent families since the 1960s is believed to be an important contributor to the increase in child poverty in the US (Waite 1995) and in the UK. US studies also show that children of one-parent families are about twice as likely to drop out of high school, in Britain children brought up in lone-parent families tend to have significantly lower educational attainment (Ermisch and Francesconi 2000). In one study the poverty element accounts for about half the child's under-performance at school, the remained apparently being due to problems to do with the division of the mother's time (McLanahan and Sandefur 1994) arising from the lack of support from a co-resident father.

Most evidence suggests that children brought up in fragmented households, compared with those from intact families, tends to suffer from more psychosocial and material handicaps - specifically in respect of school performance, discipline and subsequent parenting (e.g. Osborne et al. 2003). For example young women in the British National Child Development Study brought up in lone parent families, or in reconstituted step-families, were more likely to form sexual unions in their teens and have children early, particularly outside marriage. Teenage motherhood was twice as likely among the daughters of divorced parents compared with intact families, and if married they were more likely to divorce. Some of these handicaps endured even if the divorce occurred when the children had reached adulthood. However part of the effect, particularly the poorer qualification and employment of the young people, derived from the initial parental situation. None of these problems applied to children who lost one parent through death (Kiernan 1992, 1999). 
It is objected that these comparisons are not comparing like with like, and that the adverse consequences would have arisen whatever the setting (Barlow and Duncan 2000; Ni Bhrolchain 2001). A study based on a different sample (British Household Panel; Ermisch and Francesconi 2001), came to rather stronger conclusions in that initial parental circumstances were not found to be very important as factors in the subsequent educational, employment and psychological difficulties suffered by some of those studied. Inevitably, as cohabiting unions are less stable than marital ones, children born into such unions experience a higher level of parental disruption with its concomitant difficulties. However in the US, at least, the marriage of cohabiting parents restores the experiences of their children to the level of those born within marriage (Manning and Brown 2006).

Most of these studies have been carried out in the UK and the US where the levels of teenage motherhood are much higher than in Western Europe. Divorce is also at a high level and a higher proportion of children born outside marriage are brought up with only one parent than in Europe. It may be argued that they are less applicable elsewhere and that some of the cohort studies are based on period of time when divorce and lone parenthood were less common than now and therefore more 'selective'. This, however, may again be a special feature peculiar to the circumstances of the UK and the US.

\section{Effects on economies}

The underlying theory of the Second Demographic Transition posits radical ideational change made possible by economic progress. Are the ideational insights, once attained, irreversible irrespective of the standards of material security which made their realisation possible on a large scale? Wealth emancipates populations from anxieties about material needs and, in Europe, supports the welfare states and social housing policies on which choices of living arrangements at least partly depend. Or some of those welfare programmes have already been checked or reversed in many western societies from Sweden to New Zealand. High levels of divorce and lone parenthood transfer some of the costs of the consumption of women and the production of children to the general taxpayer. They may not be affordable in the long run. In the UK, estimates of the cost of family breakdown have ranged from $£ 4$ billion p.a. to $£ 10$ billion p.a. The Family Matters Institute (2000), estimated the direct welfare transfer costs to be $£ 15$ billion p.a., equivalent to about a third of public spending on education. Divorce creates three households for every two that existed before, and relationship breakdown has been the biggest route out of owner-occupation into state subsidised 'social' housing (Holmans et al. 1987). It may be asked whether modern economies can afford the long-term costs of the second demographic transition as well as the unavoidable and permanent drag on economic growth presented by population ageing. The age of entitlement may only temporarily have insulated people from the consequences of their reproductive actions and thereby only transiently permitted a wider spectrum of behaviour. 


\section{Conclusion}

The partial marginalization of marriage and its partial replacement by a variety of other arrangements formerly regarded as immoral, comprise the essence of the changes described in this paper. Like so much that has happened to modern populations in the last fifty years, it has no real historical precedent. How do we account for them? To sum up, it may reasonably regarded as the product of two parallel and related developments. The first is that many members of the educated and literate populations of rich countries are disinclined to be over-awed by considerations of morality or of duty derived from religion or from traditional authority. Liberated by prosperity or by the welfare which prosperity makes possible, they see few absolute impediments to giving a higher priority to their interests and personal development. Elaboration on these themes form the basis of 'post materialist' and 'postmodernist' accounts of these trends.

Secondly, and probably an essential pre-requisite, is the fundamental advancement of women in education, the workforce and public life in general. Formalised by the econometric models of the 'New Household Economics' of the Chicago and Philadelphia schools, both children and marriage emerge as losers. Small family size, if any at all, is required by the new value of a woman's time, determined by the opportunity cost of foregone earnings in circumstances where work and childcare are challenging. The economic independence of women makes the inception and continuation of marriage less necessary, and its replacement with the less committed arrangements of cohabitation more desirable. Demands from the increasing numbers of those following these paths to cohabitation and divorce then lead to legal and financial changes to improve the status of divorce and cohabitation. These serve to eliminate the legal and fiscal advantages formerly enjoyed by the married state, and make it even less appealing. Intellectual tensions continue between the proponents of these two poles of view, although they are by no means mutually exclusive.

The developments themselves are usually presented by demographers and other analysts in morally neutral terms. However a lively debate continues both among social scientists and in a wider and more political public, about whether these changes matter in terms of human and economic welfare and whether they are economically sustainable in a world about to be given the bill for the additional costs of population ageing.

\section{Acknowledgement}

The author is very grateful to Professor Anna Rotkirch and to Lassi Lainiala for their expert advice in preparing this paper. 


\section{References}

Aarskaug Wiik, K., R. Keizer and T. Lappegård. 2012. Relationship quality in marital and cohabiting unions across Europe. Journal of Marriage and Family 74(3), 389-398.

Balbo, N., F. Billari and M. Mills. 2012. Fertility in Advanced Societies: A Review of Research. European Journal of Population / Revue européenne de Démographie, $1-38$.

Barlow, A. and S. Duncan. 2000. New Labour's communitarianism, supporting families and the 'rationality mistake'. Part II. Journal of Social Welfare and Family Law 22(2): 129-143.

Barthold, J. A., M. Myrskylä and O. R. Jones. 2012. Childlessness drives the sex difference in the association between income and reproductive success of modern Europeans. Evolution and Human Behavior 33(6), 628-638.

Becker, G. S. 1981. A treatise on the family. Cambridge, MA: Harvard University Press.

Benigno, F.1989. The Southern Italian family in the early modern period: a discussion of co-residential patterns. Continuity and Change 4(1): 165-194.

Berrington, A. and I. Diamond. 2000. Marriage or cohabitation: a competing risks analysis of first-partnership formation among the 1958 British birth cohort. Journal of the Royal Statistical Society: Series A. (Statistics in Society) 163(2): 127-151.

Berrington, A. 2001. Entry into parenthood and the outcome of cohabiting partnerships in Britain. Journal of Marriage and Family 63: 80-96.

Berrington, A. and I. Diamond. 1999. Marital dissolution among the 1958 British birth cohort: the role of cohabitation. Population Studies 53(1): 19-38.

Berrington, A. and I. Diamond. 2000. Marriage or cohabitation: a competing risks analysis of first-partnership formation among the 1958 British birth cohort. Journal of the Royal Statistical Society: Series A. (Statistics in Society) 163(2): 127-151.

Billari, F. C., M. Castiglioni, T.C. Martin, F. Michielin and F. Ongaro. 2002. Household and union formation in a Mediterranean fashion: Italy and Spain. In: Dynamics offertility and partnership in Europe. Insights and lessons from comparative research, edited by E. Klijzing and M. Corijn, 2: pp. 15-42. New York and Geneva: United Nations.

Billari, F. C. and H.-P. Kohler. 2002. The Impact of Union Formation Dynamics on First Births in West Germany and Italy: are there signs of convergence? In: Dynamics of fertility and partnership in Europe. Insights and lessons from comparative research, edited by E. Klijzing and M. Corijn, 2: pp. 43-58. New York and Geneva: United Nations.

Billari, F. and C. Wilson. 2001. Convergence towards diversity? Cohort dynamics in the transition to adulthood in contemporary Western Europe. Max Planck Institute for Demographic Research, Working Paper WP2001-039.

Blumstein, P. and P. Schwartz. 1983. American couples. New York: Morrow.

Bongaarts, J. and G. Feeney. 1998. On the Quantum and Tempo of Fertility. Population and Development Review 24(2): 271-291.

Bracher, M., G. Santow, S.P. Morgan and J. Trussell. 1993. Marriage dissolution in Australia: Models and explanations. Population Studies 47(3): 403-425. 
Caradec, V. 1996. Les formes de la vie conjugale des ‘jeunes' couples ‘ages'. Population 51: 897-928.

Chapple, S. 2009. Child Well-Being and Sole- Parent Family Structure in the OECD. OECD Social Employment and Migration Working Papers, 82.

Cliquet, R. L. 1991. The second demographic transition: Fact or fiction? Strasbourg: Council of Europe.

Coale, A. J. and S. C. Watkins. 1986. The decline of fertility in Europe. Princeton: Princeton University Press.

Coleman, D. A. 2002. Populations of the industrial world - a convergent demographic community? International Journal of Population Geography 8: 319-344.

Coleman, D. A. and T. Chandola. 1999. Britain's place in Europe's population. In: Changing Britain: Families and households in the 1990s, edited by S. McRae, pp. 37-67. Oxford: Oxford University Press.

Council of Europe. 2003. Recent Demographic Developments in Europe 2002. Strasbourg: Council of Europe Press.

Crafts, N. F. R. and T. C. Mills. 1995. Europe's golden age: An econometric investigation of changing trend rates of growth. Discussion Paper No 1087. London: Centre for Economic Policy Research.

De Vries, J. 1986. The population and economy of the preindustrial Netherlands. In: Population and economy, edited by R. I. Rothberg and T. K. Rabb, pp. 101-122. Cambridge, Cambridge University Press.

Dnes, A. W. 2002. Cohabitation and marriage. In: The law and economics of marriage and divorce, edited by A. W. Dnes and R. Rowthorn, pp. 118-131. Cambridge, Cambridge University Press.

Dnes, A. W. and R. Rowthorn, Eds. 2002. The law and economics of marriage and divorce. Cambridge, Cambridge University Press.

Dourleijn, E. and A. Liefbroer. 2002. Unmarried cohabitation and union stability: a test of the selection hypothesis using data from 16 European countries. Divorce in a Cross-national Perspective: A European Research Network, Florence.

Ermisch, J. 2000. Employment Opportunities and Pre-marital Births in Britain. Colchester: Institute for Social and Economic Research.

Ermisch, J. and M. Francesconi. 2000. Cohabitation in Great Britain: not for long, but here to stay. Journal of the Royal Statistical Society A 163 (Part 2): 153-171.

Ermisch, J. and M. Francesconi. 2001. The effects of parents'employment on children's lives. London: The Policy Press.

Family Matters Institute. 2000. The cost of family breakdown. London: Family Matters Institute. Available from: http://www.familymatters.org.uk/cfb.html

Fihel, A. 2004. Cohabitation in Poland-social and economic determinants of union formation. Faculty of Economics. Warsaw: Warsaw University.

Flinn, M. W. 1981. The European demographic system 1500-1820. Baltimore: Johns Hopkins University Press.

Gierveld, J. d. J. and A. Peeters. 2003. The interweaving of repartnered older adults' lives with their children and siblings. Ageing \& Society 23: 187-205.

Goody, J. 1996. Comparing family systems in Europe and Asia. Population and 
Development Review 22(1): 1-20.

Haavio-Mannila, E. and A. Rotkirch. 2010. Sexuality and family formation. In: Handbook of European Societies, edited by S. Immerfall and G. Therborn. New York: Springer.

Hajnal, J. 1965. European marriage patterns in perspective. In: Population in History, edited by D.V. Glass and D.E.C. Eversley. London: Arnold.

Hajnal, J. 1982. Two kinds of preindustrial household formation systems. Population and Development Review 8(3): 449-94.

Haskey, J. 1992. Patterns of marriage, divorce, and cohabitation in the different countries of Europe. Population Trends 69: 27-36.

Haskey, J. 1996. The proportion of married couples who divorce: past patterns and current prospects. Population Trends 83: 25-36.

Haskey, J. 1999. Cohabitational and marital histories of adults in Great Britain. Population Trends 96:13-24.

Haskey, J. 2001. Cohabitation in Great Britain: Past, present and future trends - and attitudes. Population Trends 103: 4-19.

Haskey, J. 2005. Living arrangements in contemporary Britain: Having a partner who usually lives elsewhere and Living Apart Together (LAT). Population Trends 122, Winter 2005: 35-45.

Hinde, P. R. A. 1998. Demographic methods. London: Arnold.

Hoem, B. and J. M. Hoem. 1992. The disruption of marital and non-marital unions in contemporary Sweden. In: Demographic applications of event history analysis, edited by J. Trussell, R. Hankinson and J. Tilton, pp. 61-93. Oxford: Clarendon Press.

Holmans, A. E., Nandy, S. and A.C. Brown. 1987. Household formation and dissolution and housing tenure: a longitudinal perspective. Social Trends 17: 20-28.

Holmes, J. and K. Kiernan. 2010. Fragile families in the UK: Evidence from the Millennium Cohort Study. York: University of York, Department of Social Policy and Social Work.

Houston, R. A. 1992. The population history of Britain and Ireland 1500-1750. London: Macmillan.

Kalmijn, M. 2007. Explaining cross-national differences in marriage, cohabitation, and divorce in Europe, 1990-2000. Population Studies 61(3): 243-263.

Kiernan, K. 1992. The impact of family disruption in childhood on transitions made in young adult life. Population Studies 46: 213-234.

Kiernan, K. 1999. Cohabitation in Western Europe. Population Trends 96: 25-32.

Kiernan, K. 2002a. The state of European Unions: an analysis of partnership formation and dissolution. In: Dynamics of fertility and partnership in Europe, Volume 1. Proceedings of the Family and Fertility Surveys Flagship Conference, Brussels 2000, edited by M. Macura and G. C. N. Beets, 1: pp. 57-76. New York and Geneva: United Nations. Kiernan, K. 2002b. Cohabitation in Western Europe: Trends, issues and implications. In: Just living together: Implications of cohabitation on families, children and social policy, edited by A. Booth and A. Crouter. New Jersey: Lawrence Erlbaum.

Kiernan, K. 2004. Unmarried cohabitation and parenthood in Britain and Europe. Law \& Policy 26(1): 33-55. 
Klijzing, E. 1992. 'Weeding' in the Netherlands: First-union disruption among men and women born between 1928 and 1965. European Sociological Review 8(1): 53-70.

Koytcheva, E. and D. Philipov. 2008. Ethnic differentials in rapidly declining fertility. Demographic Research 19(13): 361-402.

Kuijsten, A. C. 1996. Changing family patterns in Europe: A case of divergence? European Journal of Population 12: 115-143.

Kussmaul, A. S. 1979. Servants in husbandry in early modern England. Journal of Economic History 39(1): 329-331.

Kyvelidis, I. 2001. Measuring post-materialism in post-socialist societies. European Integration Online Papers 5(2): 14.

Laslett, P., K. Oosterveen and R. W. Smith (eds) 1980. Bastardy and its comparative history: studies in the history of illegitimacy and marital nonconformism in Britain, France, Sweden, North America, Jamaica and Japan. London: Arundel.

Lee, J. and W. Feng. 1999. Malthusian models and Chinese realities: China's demographic system 1700-2000. Population and Development Review 25(1): 33-66.

Lesthaeghe, R. 1983. A century of demographic and cultural change in Western Europe. Population and Development Review 9: 411-436.

Lesthaeghe, R. 1995. The second demographic transition in Western countries: An interpretation. In: Gender and family change in industrialized countries, edited by K. O. Mason and A-M. Jensen, pp. 17-62. Oxford: Clarendon Press.

Lesthaeghe, R. and J. Surkyn. 2004. When history moves on: the foundations and diffusion of a second demographic transition. Brussels, Interface Demography: Free University of Brussels.

Lesthaeghe, R. 2010. The unfolding story of the second demographic transition. Population and Development Review 36(2): 211-251.

Lesthaeghe, R. and Meekers, D. 1986. Value changes and the dimensions of familism in the European Community. European Journal of Population 2: 225-268.

Levin, I. and J. Trost. 1999. Living apart together. Community, Work and Family 2(3): 279-294.

Levin, I. 2004. Living apart together: a new family form. Current Sociology 52(2): 223-240.

Lichter, D. T., D. Graefe and J.B. Brown. 2003. Is marriage a panacea? Union formation among economically disadvantaged unwed mothers. Social Problems 50(1): 60-89.

Liefbroer, A. C. and T. Fokkema. 2008. Recent developments in demographically relevant attitudes and behaviour: New challenges for a new era? In: Demographic challenges for the 21st Century. A state of art in demography, edited by J. Surkyn, P. Deboosere and J. van Bavel, pp. 115-141. Brussels: VUB Press.

Lillard, L. A., M. J. Brien and L.J. Waite. 1995. Premarital cohabitation and subsequent marital dissolution: a matter of self-selection? Demography 32(3): 437-457.

Macfarlane, A. 1986. Marriage and love in England 1300-1840. Oxford: Basil Blackwell.

Macura, M. and G. Beets (eds.) 2002. Dynamics of fertility and partnership in Europe: insights and lessons from comparative research. (2 volumes) New York: United Nations. 
Manning, W. D. and S. Brown. 2006. Children's economic well-being in married and cohabiting parent families. Journal of Marriage and Family 68(2): 345-362.

Manting, D. 1996. The changing meaning of cohabitation and marriage. European Sociological Review 12(1): 53-65.

McLanahan, S. and G. Sandefur. 1994. Growing up with a single parent - what hurts, what helps. Cambridge MA: Harvard University Press.

McLanahan, S. and C. Percheski. 2008. Family structure and the reproduction of inequalities. Annual Review of Sociology 34(1): 257-276.

Menefee, S. P. 1981. Wives for sale: An ethnographic study of British popular divorce. Oxford: Basil Blackwell.

Micheli, G. A. 2000. Kinship, family and social network. The anthropological embedment of fertility change in Southern Europe. Demographic Research 3(13).

Milan, A. and A. Peters. 2003. Couples living apart. Canadian Social Trends (Summer 2003): 2-6.

Mitterauer, M. and Sieder, R. 1982. The myth of the large pre-industrial family. Chapter 2 of The European Family (same authors), pp. 24-47. Oxford: Basil Blackwell.

Morgan, P. 2000. Marriage-Lite: the rise of cohabitation and its consequences. London: Civitas.

Ni Bhrolchain. 1993. East West marriage contrasts old and new. In: European Population ii. Demographic dynamics vol. 2, edited by A. Bllum and J.-L. Rallu, pp. 461-482. London: John Libbey.

Ni Bhrolchain, M. 2001. 'Divorce effects' and causality in the social sciences. European Sociological Review 17: 33-57.

O Grada, C. 1993. Ireland before and after the Famine: explorations in economic history 1800-1925. 2nd edition. Manchester: Manchester University Press.

Osborne, C., S. McLanahan and J. Brooks-Gunn. 2003. Is there an advantage to being born to married versus cohabiting parents? Working Paper \# 03-09-FF. Princeton: Center for Research on Child Wellbeing: 41.

Palomba, R. 2001. Postponement in family formation in Italy, within the southern European context. Paper presented International Union for the Scientific Study of Population working group on low fertility meeting, Tokyo.

Palomba, R. and H. Moors. 1995. The image of the family. In: Population, family and welfare: A comparative survey of European Attitudes Vol. 2, edited by R. Palomba and H. Moors, pp. 72-93. Oxford: Oxford University Press.

Phillips, R. 1988. Putting Asunder: A history of divorce in Western society. Cambridge: Cambridge University Press.

Perelli-Harris, B., M. Kreyenfeld, W. Sigle-Rushton, R. Keizer, T. Lappegård, A. Jasilioniene, C. Berghammer and P. Di Giulio. 2012. Changes in union status during the transition to parenthood in eleven European countries, 1970s to early 2000s. Population Studies 66(2): 167-182.

Philipov, D. 2001. Low fertility in Central and Eastern Europe: Culture or economy? International Perspectives on Low Fertility: Trends, Theories and Policies. Tokyo: IUSSP. 
Philipov, D. and J. Dorbritz. 2003. Demographic consequences of economic transition in countries of Central and Eastern Europe. Council of Europe Population Studies 23, Strasburg: Council of Europe.

Raymo, J. M., M. Iwasawa and L. Bumpass. 2008. Cohabitation and family formation in Japan. Discussion paper No. 714. Osaka: The Institute of Social and Economic Research, Osaka University

Reher, D. S. 1998. Family ties in Western Europe: Persistent Contrasts. Population and Development Review 24(2), 203-234.

Rosenzweig, M. R. 1999. Welfare, marital prospects and nonmarital childbearing. Journal of Political Economy 107: S3-S32.

Roussel, L. 1995. Vers une Europe des familles? Futuribles, 200, 47-62.

Rowthorn, R. 2002. Marriage as a signal. In: The law and economics of marriage and divorce, edited by A. W. Dnes and R. Rowthorn. pp. 132-156. Cambridge: Cambridge University Press.

Rowthorn, R. and D. Webster. 2008. Male worklessness and the rise of lone parenthood in Britain. Cambridge Journal of Regions, Economy and Society 1: 69-88.

Ruggles, S. 2009. Reconsidering the Northwest European family system: Living arrangements of the aged in comparative historical perspective. Population and Development Review 35(2): 249-273.

Rychtarikova, J. 1993. Nuptialité comparée en Europe de l'Est et en Europe de l'ouest. European Population ii. Demographic dynamics, 2: pp. 191-210. London: John Libbey.

Sardon, J.-P. and G. Calot. 1997. Le reprise de la fecondite au milieu des annees trente, phenomène non perçu des observateurs du temps. Saint-Germain-en-Laye: Observatoire Demographique Europeen.

Shaw, C. 1999. 1996-based population projections by legal marital status for England and Wales. Population Trends 95: 23-32.

Smith, R.M. (ed). 1986. Land, Kinship and Life-Cycle. Cambridge: Cambridge University Press.

Sobotka, T., K. Zeman and V. Kantorova. 2003. Demographic shifts in the Czech republic after 1989: A second demographic transition view. European Journal of Population 19(3): 249-277.

Sobotka, T. 2008. The diverse faces of the second demographic transition in Europe. Demographic Research 19(8): 171-224.

Szoltysek, M. A. 2007. Central European household and family systems, and the 'Hajnal -"Mitterauer' line: The parish of Bujakow. 18 ${ }^{\text {th }}-19$ th centuries. The History of the Family 12(1): 19-42.

Szoltysek, M. A. 2008. Three kinds of preindustrial household formation system in historical Eastern Europe: A challenge to spatial patterns of the European family. The History of the Family 13(3): 223-257.

Szreter, S. 1996. Falling fertilities and changing sexualities in Europe since c. 1850: a comparative survey of national demographic patterns. Working Papers in Demography No 62: 35. Australian National University Research School in Social Sciences. 
Teachman, J. D., J. Thomas and K. Paasch. 1991. Legal Status and the stability of coresidential unions. Demography 28(4): 571-586.

Therborn, Göran. 2004. Between sex and power. Family in the world, 1900-2000. London: Routledge.

Toulemon, L. 1996. La cohabitation hors mariage s'installe dans la duree. Population 51(3): 715-673.

Trussel, J., G. Rodriguez and B. Vaughan. 1992. Union dissolution in Sweden. In: Demographic applications of event history analysis, edited by J. Trussel, R. Hankinson and J. Tilton, pp. 38-60. Oxford: Clarendon Press.

United Nations Population Division. 2012. World marriage data 2012. Available from http://www.un.org/en/development/desa/population/publications/dataset/marriage/ wmd2012.shtml

Villeneuve-Gokalp, C. 1997. Vivre en couple chacun chez soi. Population 52(5): 1059-1082.

Waite, L. J. 1995. Does marriage matter? Demography 32(4): 483-507.

Willekens, F. 1999. The Life Course: Models and Analysis. In: Population issues: an interdisciplinary focus, edited by L. J. G. van Wissen and P. A. Dykstra, pp. 23-51. Dordrecht: Kluwer.

Willis, R. J. 1999. A theory of out-of-wedlock childbearing. Journal of Political Economy 107: S33-S64.

Winkler-Dworak, M. and H. Engelhardt. 2002. On the tempo and quantum of first marriages in Austria, Germany, and Switzerland: Changes in mean age and variance. Demographic Research 10(9): 231-263.

Wrigley, E.A. and Schofield, R. 1981. The population history of England 1541-1871. Part 2. London: Edward Arnold.

Wrigley, E. A. 1986. Malthus's Model of a Pre-Industrial economy. In: Malthus and his time, edited by M. Turner, pp. 3-18. Houndmills: Macmillan.

Wrigley, E. A., R. S. Davies, J. E. Oeppen, and R. S. Schofield. 1997. English population history from family reconstitution 1580-1837. Part 2. Cambridge: Cambridge University Press. 